\title{
A Study of Innovation: ERD Takes Pollution Prevention to a New Level
}

by

A. Southmayd

Westinghouse Savannah River Company

Savannah River Site

Aiken, South Carolina 29808

This paper was prepared in connection with work done under the above contract number with the U.S. Department of Energy. By acceptance of this paper, the publisher and/or recipient acknowledges the U.S. Government's right to retain a nonexclusive, royalty-free license in and to any copyright covering this paper, along with the right to reproduce and to authorize others to reproduce all or part of the copyrighted paper. 


\section{DISCLAIMER}

This report was prepared as an account of work sponsored by an agency of the United States Government. Neither the United States Government nor any agency thereof, nor any of their employees, makes any warranty, express or implied, or assumes any legal liability or responsibility for the accuracy, completeness, or usefulness of any information, apparatus, product, or process disclosed, or represents that its use would not infringe privately owned rights. Reference herein to any specific commercial product, process, or service by trade name, trademark, manufacturer, or otherwise does not necessarily constitute or imply its endorsement, recommendation, or favoring by the United States Government or any agency thereof. The views and opinions of authors expressed herein do.not necessarily state or reflect those of the United States Government or any agency thereof.

This report has been reproduced directly from the best available copy.

Available to DOE and DOE contractors from the Office of Scientific and Technical Information, P. O. Box 62, Oak Ridge, IN 37831; prices available from (423) 576-8401.

Available to the public from the National Technical Information Service, U. S. Department of Commerce, 5285.Port Royal Road, Springfield, VA 22161. 


\section{DISCLAIMER}

Portions of this document may be illegible in electronic image products. Images are produced from the best available original document. 


$$
\text { WSRC-MS-98-00807 }
$$
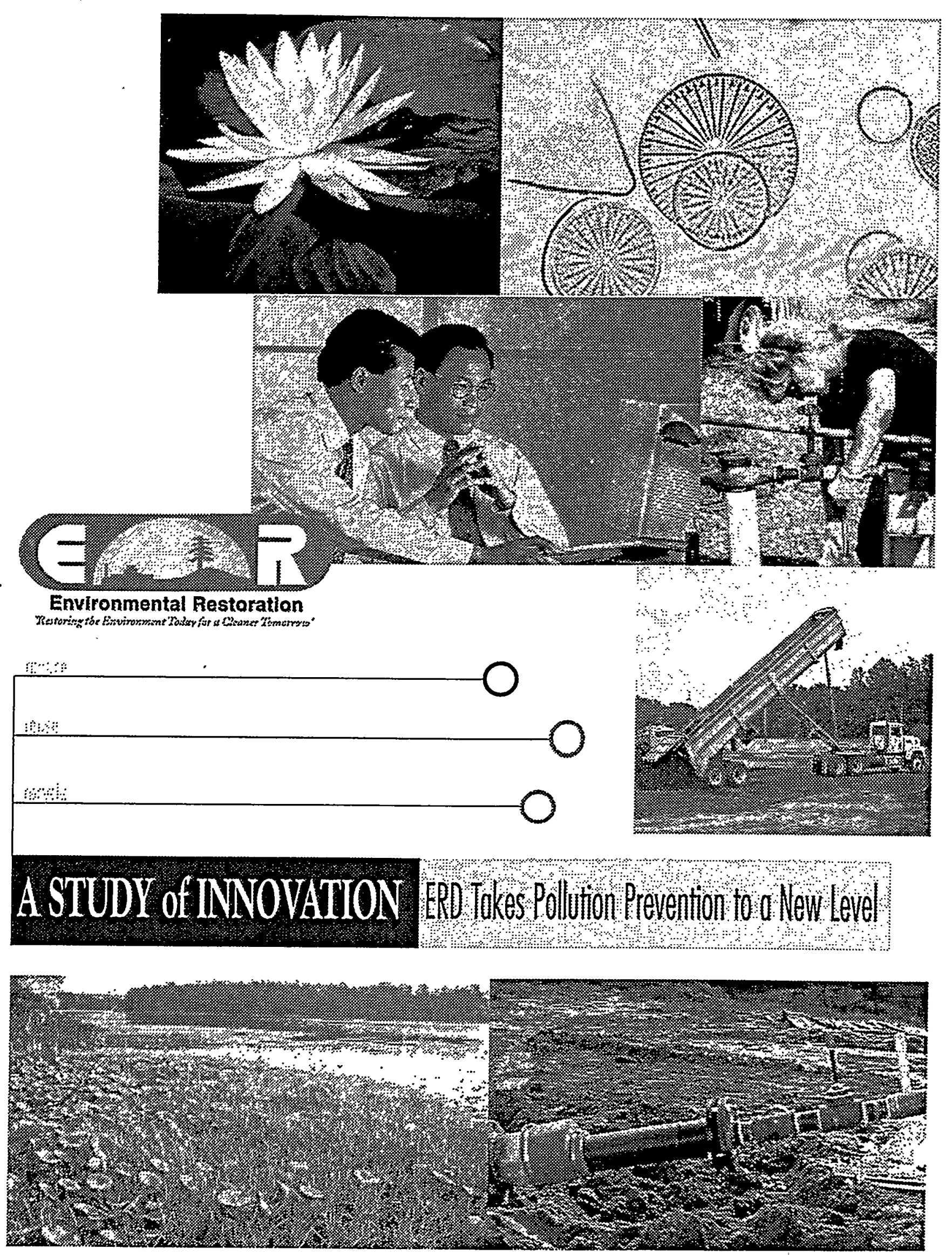


\section{WSRC-MS-98-00807 \\ A STUDY OF INNOVATION}

ERD Takes P Ollution Prevention to a New Level

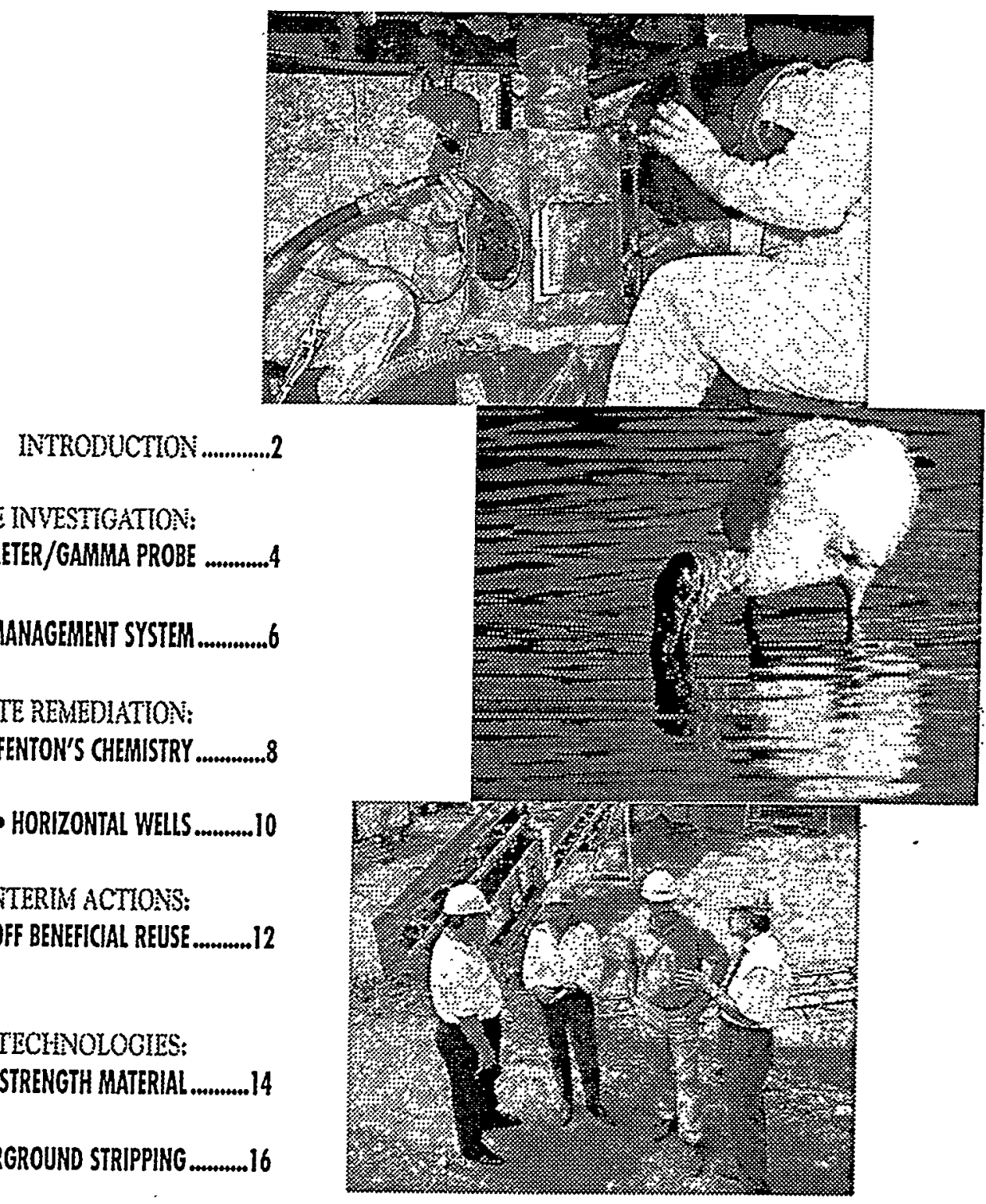

- PHYTOREMEDIATION...........18

- PHOSTER ...........20

- FIELD DEPLOYABLE TRITIUM ANALYSIS..........22

Natuse Pholos by

David Scott, SREL 


\section{WSRC-ms-98.00807}

I nnovation is the watchword as the Savannah River Site's (SRS) Environmental Restoration Division (ERD) aggressively pursues the challenge of preventing pollution and minimizing waste while cleaning IIHOYATIOH: o dionger somating neit or tertive up the environment. As SRS approaches the 21st Century, ERD takes its pollution prevention (P2) program beyond the building blocks of "Reduce, Reuse, Recycle" to a new level - one of innovative technology deployment and thinking outside of the box.

For more than 40 years, SRS produced weaponsgrade nuclear materials, conducted nuclear research in support of our nation's defense programs, and supported other non-defense government missions. The end of the Cold War signaled a shift in priorities from nuclear materials production and research to environmental cleanup and nuclear materials stabilization, storage, and disposal. The requirement to balance the federal budget resulted in budger reductions and workforce downsizing. To support these changes, SRS made a commitment to adape and work to enhance our nation's security, reduce the risk of nuclear proliferation, accelerate environmental cleanup, and advance mission-related science and technology.

With this commirment in mind, ERD approaches its mission with a vision of continuously exceeding customer needs and expectations and continuously improving. It's this.vision of continuous improvement that drives the ERD pollution prevention program towards innovation. Technological breakthroughs and new ideas on how to do the job better are essential to continuous improvement. integrating pollution prevention initiatives into site cleanup projects is demonstrated by the establishment of a pollution prevention group within the division.

The pollution prevention group works with ERD project managers to emphasize enhanced work planning, encourage waste forecasting, and establish quantifiable waste reduction goals. ERD prepares a Pollution Prevention Opportunity Assessment (PPOA) that addresses the waste-generating activities associated with each ERD project. The PPOA compiles information pertaining to a project's objectives, work plan, and waste streams and identifies improvements that will avoid or minimize the production of waste.

Once $\mathrm{P} 2$ opportunities are identified, ERD pollution prevention professionals work with ERD project managers and Savannah River Technology Center (SRTC) researchers to compare innovative and conventional remediation technologies and determine which technologies are most efficient and most cost effective in reducing waste volumes and achieving project remediation objectives.

\section{Environmental Restoration Division}

Mission: remediate waste sites and groundwater units, reduce risk to the environment for future land use, and demonstrate capabilities to attract and succeed in new missions.

Vision: continuously exceed the needs and expectations of our customers and become recog. nized as best for environmental restoration through the application of innovative technolo. gies, a strong commitment to teamwork, highly qualified personnel, and attention to continuous improvement. 


\section{WSRC-ms-98-00807}

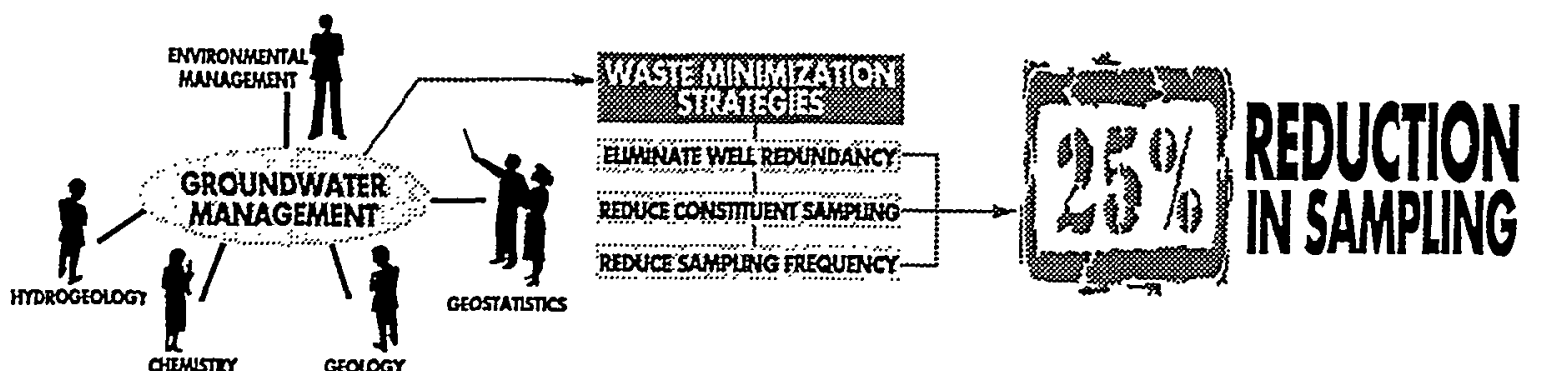

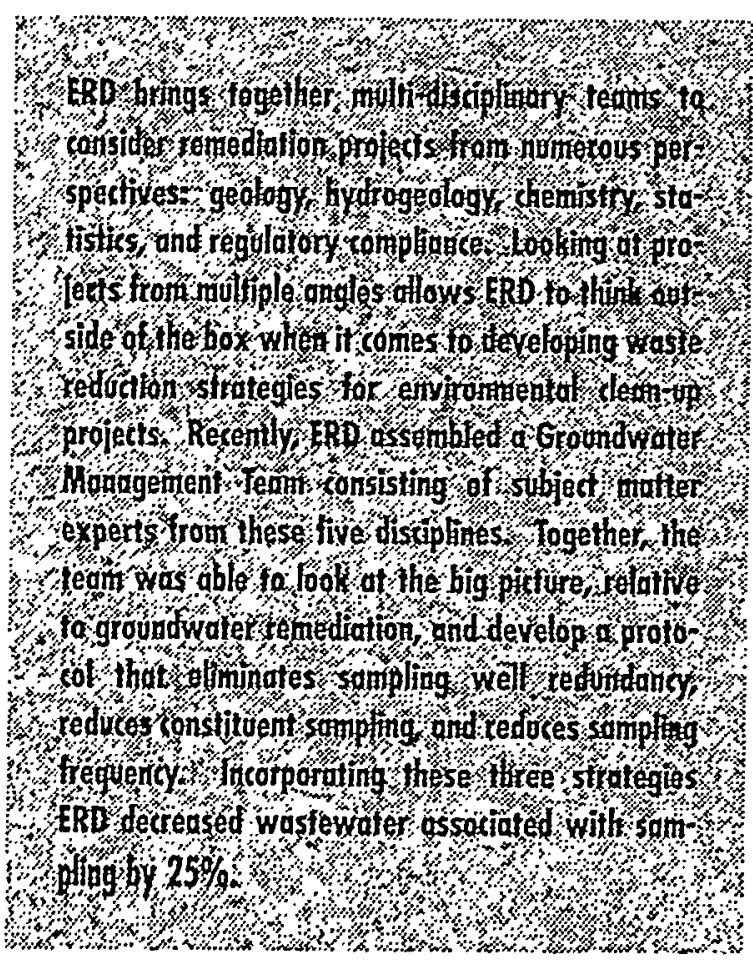

Successful implementation of ERD pollution prevention initiatives requires planning. To sustain development and implementation of P2 activities while cleaning up the more than 450 surface and groundwater waste units, ERD utilizes a P2 Program Implementation Plan. The ERD P2 Plan identifies the ERD P2 vision, goals, evaluation criteria, responsible personnel, and program objectives and actions. Identifying innovative P2 techniques and technologies is the first of eight objectives that direct ERD P2 Program activities:

1. Identify innovative P2 techniques and technologies with ERD applicability
2. Improve current $P 2$ techniques and rechnologies for further volume reductions

3. Develop incentives for subcontractor participation in $\mathrm{P} 2$ efforts

4. Develop an evaluation system to ensure continuous improvement in $\mathrm{P} 2$ performance

5. Promote $\mathrm{P} 2$ through management support, policies, procedures, training, and awareness

6. Develop a self-assessmenr procedure to ensure compliance with the ERD P2 Program Plan

7. Develop accurate waste volume forecasts for environmental restoration activities

8. Ensure training (department-specific) of all waste generator personnel

The Plan specifically addresses minimizing the generation of sanitary, radioactive, hazardous, and mixed waste in three of ERD's major waste-generating activities:

- Waste Site Investigation

- Waste Site Remediation

- Removal/Interim Action

The following pages highlight technological breakthroughs and innovative approaches that ERD has used or plans to use in the future. 
T The Cone Penetrometer/Gamma Probe is a state-of-the art in situ measurement tool that SRS uses in place of conventional soil sampling equipment to perform soil testing

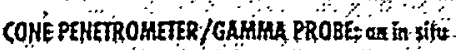

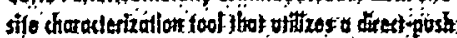

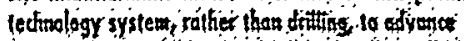

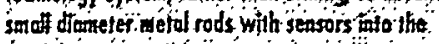
grosingt. and determine radionuclide concentrations in soils below the surface of waste sites.

A truck equipped with a hydraulic direct-push technology deploys the cone penetrometer rod or gamma probe. The probe measures the physical parameters of the subsurface and characterizes the geology of the push locations. The probe then transmits analog signals up an electrical cable to the truck where the real-time data is used to immediately identify radionuclides in the soil. The gamma probe can also be fitted with sensors that determine chemical parameters in the soil and with equipment that samples groundwater and gas below the surface.

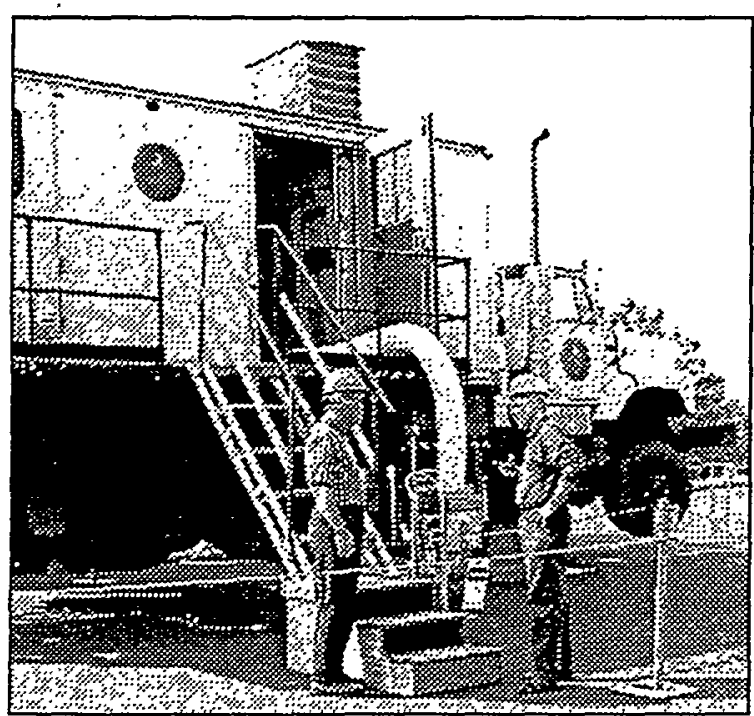

The P2 implications of using the cone penetrometer are significant. This tool eliminates the waste resulting from soil sampling (i.e., the sample itself and laboratory waste generated during analysis of the sample). Additionally, use of the direct-push system for deployment of the probe, rather than drilling, eliminates well installation and the soil waste it generates. Conventional rotary drilling methods can produce several cubic feet of waste.

Significant cost savings also result from using this tool. The expense of taking a sample, transporting and handling the sample, analyzing the sample, and disposing of the sample, laboratory wastes and other investigation-derived waste are all eliminated. 


\section{WSRC-MS- $98-00807$}
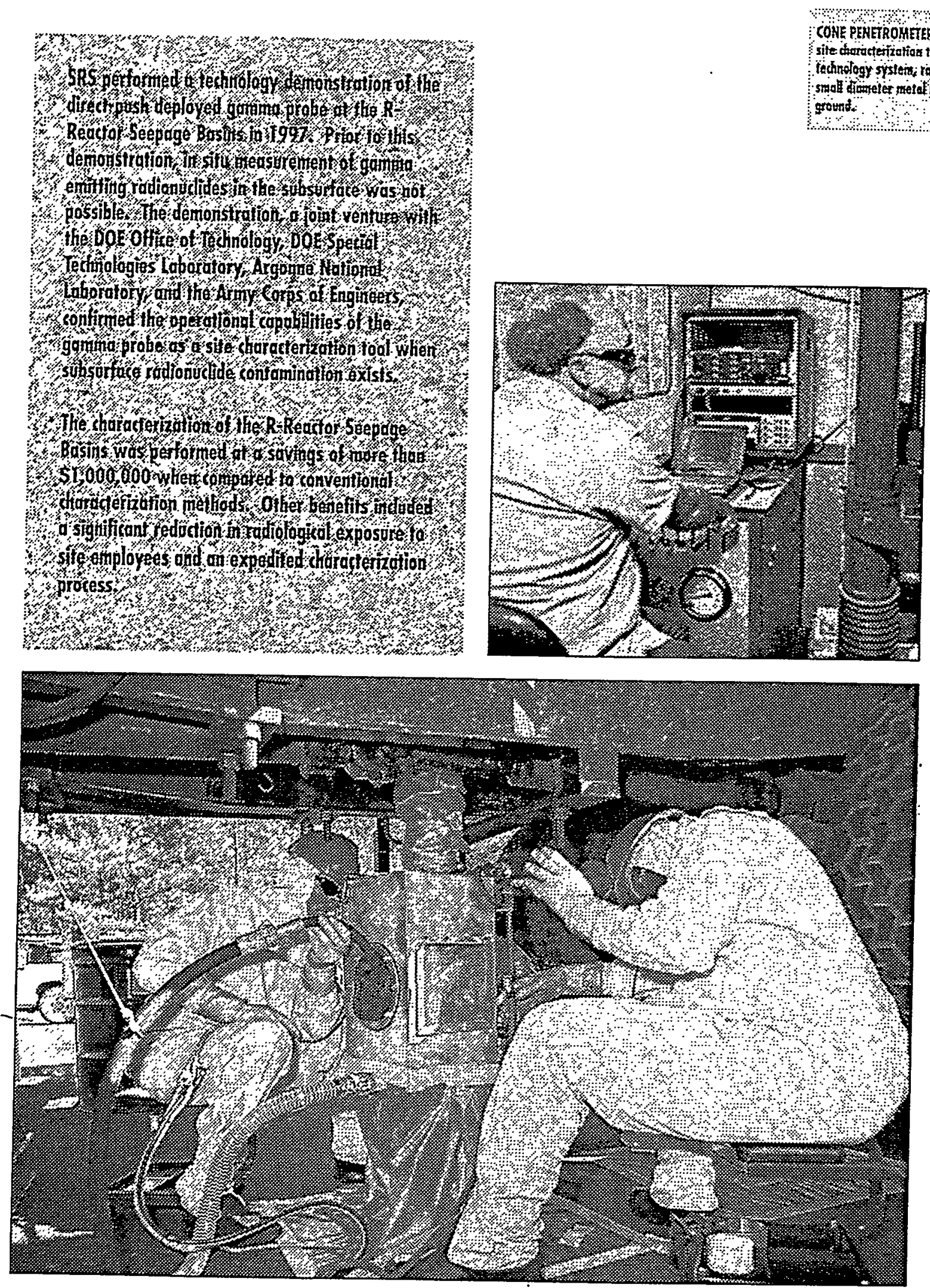
PURGE WATER MAMIGGHENT SYSTEM Q

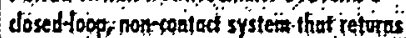

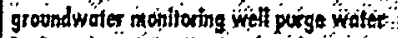
bod to the originoting oquiter of ter a sempling

avent.

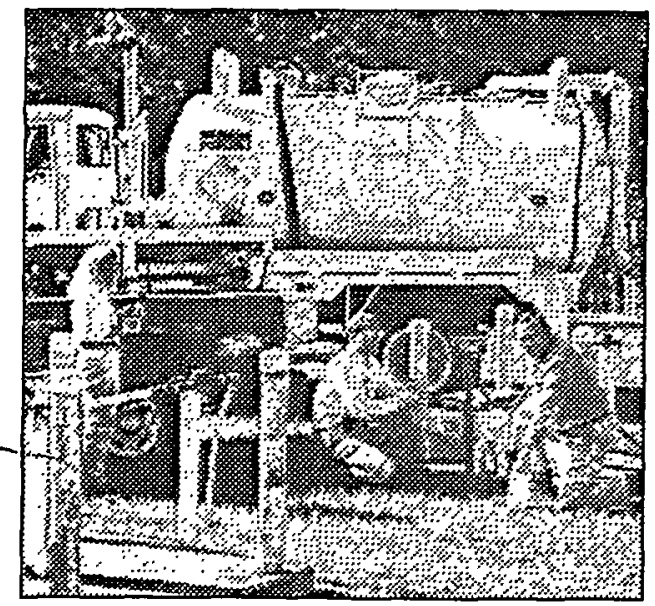

7 he Purge Water Management System (PWMS) is an innovative technology developed by SRS to manage purge water generated during the sampling of groundwater monitoring wells. This closed-loop, non-contact system returns purge water to the originating aquifer after sampling without significantly altering the water quality.

Traditional sampling methods require the purging of three to five well volumes prior to the collection of a protocol sample. The SRS groundwater monitoring network consists of nearly 2,100 wells and generates a total volume of more than 441,000 gallons of purge water annually.

In the past, purge water was discarded on the ground adjacent to the sampled well. However, in 1991, the U. S. Environmental Protection Agency (EPA) mandated the management of purge water as a hazardous waste when it contains hazardous, mixed, or radiological constituents that exceed certain threshold levels. In response, SRS instituted a complex Investigation-Derived Waste Management Plan (IDWP) as a strategy for managing purge water. The IDWP used a fleet of tanker trucks to collect purge water and transport it to SRS air strippers or an effluent treatment facility for treatment.
The PWMS is much simpler than the IDWP. It consists of a bladder contained within a steel tank, a supply system, and a return system. The PWMS connects to the monitoring well's discharge pipe and water level measurement orifice. A submersible pump, located within the monitoring well, pumps groundwater through the supply system into the bladder, which expands in direct proportion to the volume of water introduced. After a sufficient quantity of groundwater is purged from the well and certain water quality parameters are stabilized, a technician takes the required protocol groundwater samples from the well sampling port. The purge water, held in the bladder, returns to the originating aquifer by gravity feed through return piping.

Waste minimization is one of the primary benefits of the PWMS since returning contaminated purge water to the originating aquifer totally eliminates the generation of waste. Full-scale implementation of the PWMS will eliminate the production of 126,000 gallons of aqueous waste: nearly 92,000 gallons of non-radioactive purge water currently containerized and treated by a site air stripper and 34,000 gallons of radioactively-contaminated purge water currently containerized and transported to the site effluent treatment facility.

Other benefits of the PWMS include the elimination of containerization and storage areas; the elimination of tanker trucks and water buffaloes; the elimination of personnel affiliated with transportation and packaging, the effluent treatment facility and health protection; and an accelerated schedule which reduces purge water management costs. 


\section{WSRC-MS-98-00807}

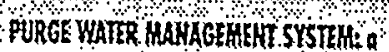

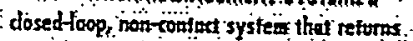

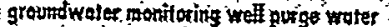
bedk to the originating uquifer dfer is scimptians eventi:
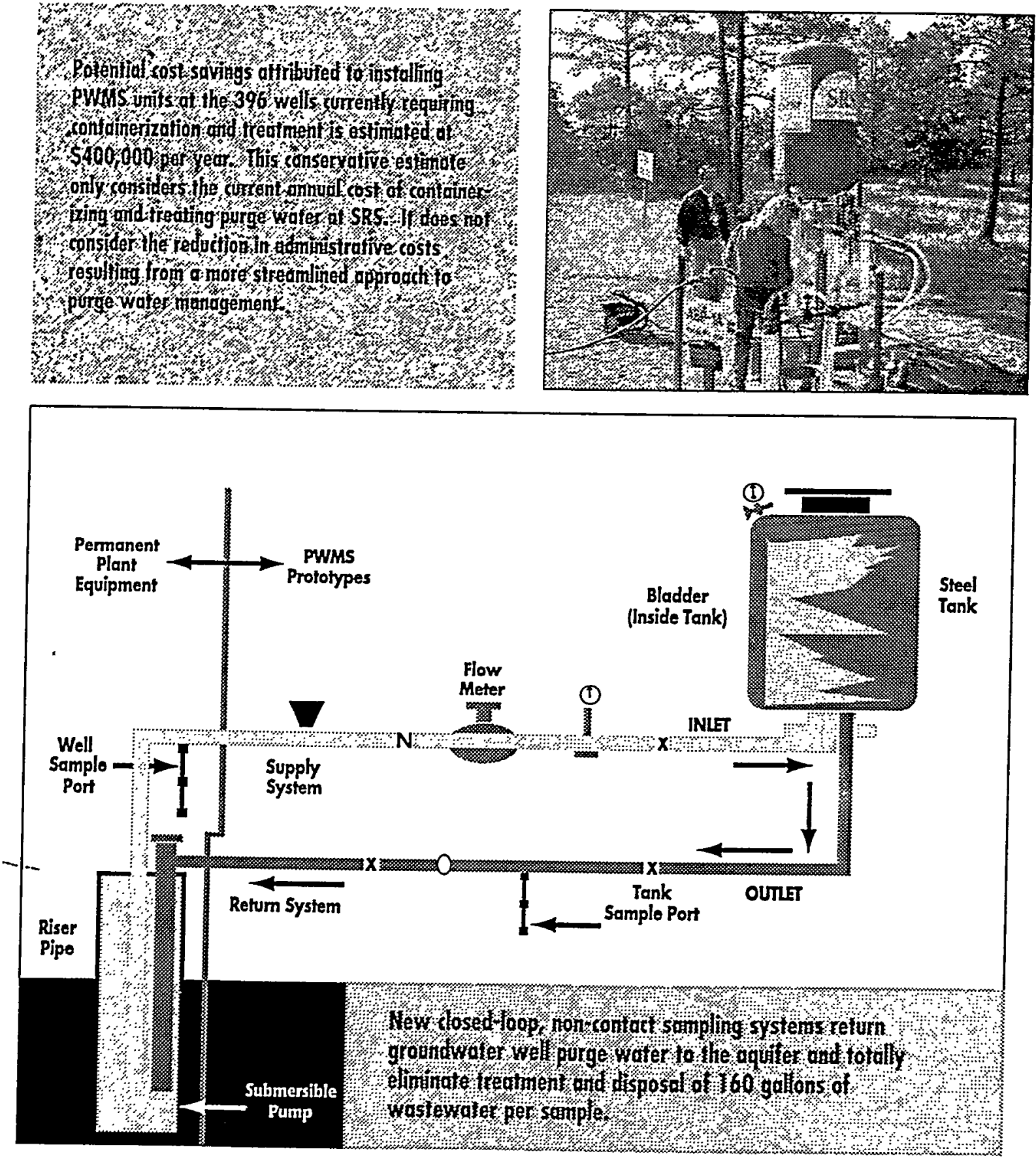


$$
\text { WSRC-ms-98.00807 }
$$

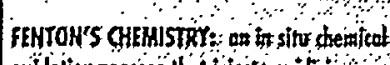

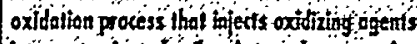
into contartial of sol and groond watex ond

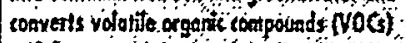

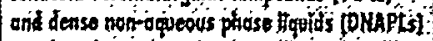

into hermless, neto of couppounds: treat the contaminants.

This chemical oxidation process increases the permeability of most subsurface soils and then chemically converts the organic contaminants to

This technology uses specially designed equipment and injection wells to disperse a powerful solution of oxidizers, catalysts, and other nonhazardous and environmentally safe compounds into contaminated subsurface soils and groundwater and destroy/

Enton's Chemistry is a patented in situ
chemical oxidation technology that SRS treat technologies to remediate groundwater contamination.

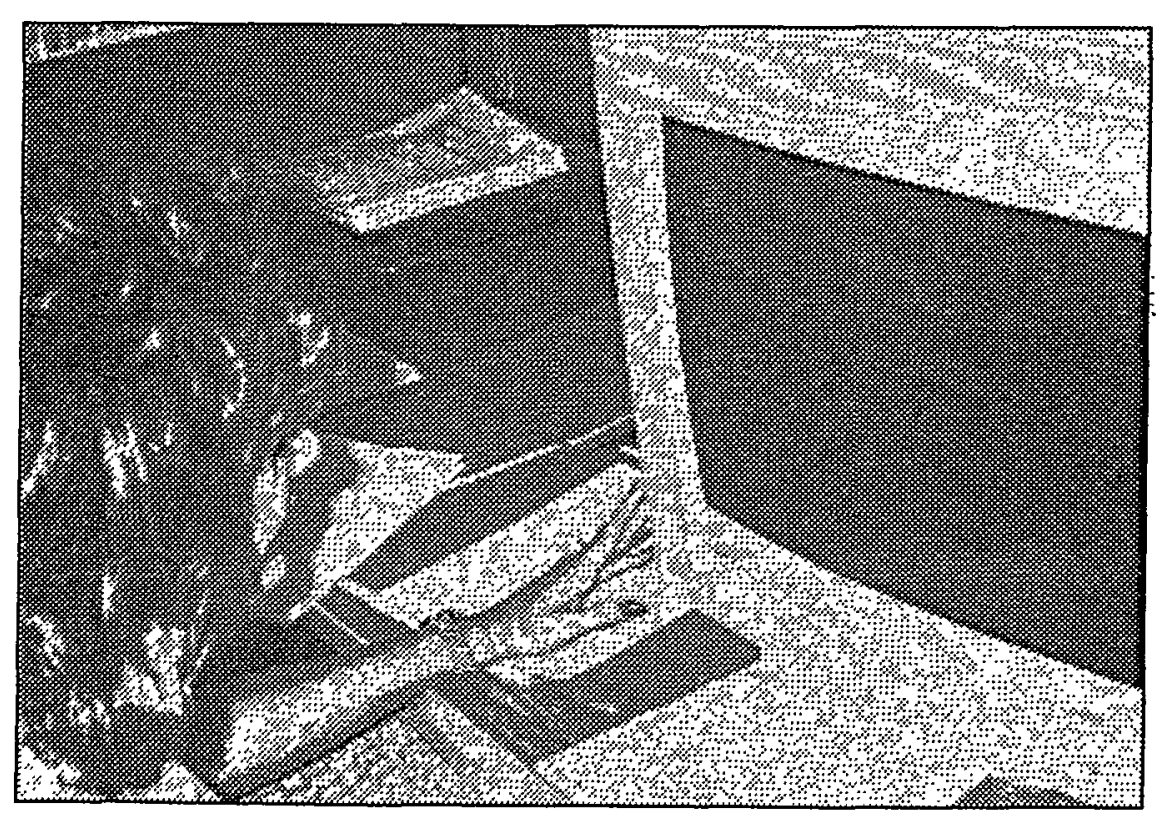

carbon dioxide, water, and chloride ions, all considered innocuous materials. Any remaining reagents are converted into oxygen and water or continue to be used as nutrients by microorganisms in the soil and groundwater.

The Fenton's Chemistry technology complements ERD's $P 2$ programs. No waste is generated from the treatment process, and no material is brought to the surface.

Since the Fenton's Chemistry technology destroys DNAPLs in its purest form, each gallon of concentrate that is removed and treated eliminates more than a million gallons of water that would be treated by conventional methods.

Remediation using this innovative technology significantly reduces or totally eliminates organic contaminants. Destroying the DNAPLs while they're still concentrated precludes cleaning millions of gallons of water and tons of soil. The environment can be cleaned faster and more cost effectively; potential cost savings are estimated at 60 cents per 1,000 gallons treated. 


\section{WSRC - ms-98-00807}

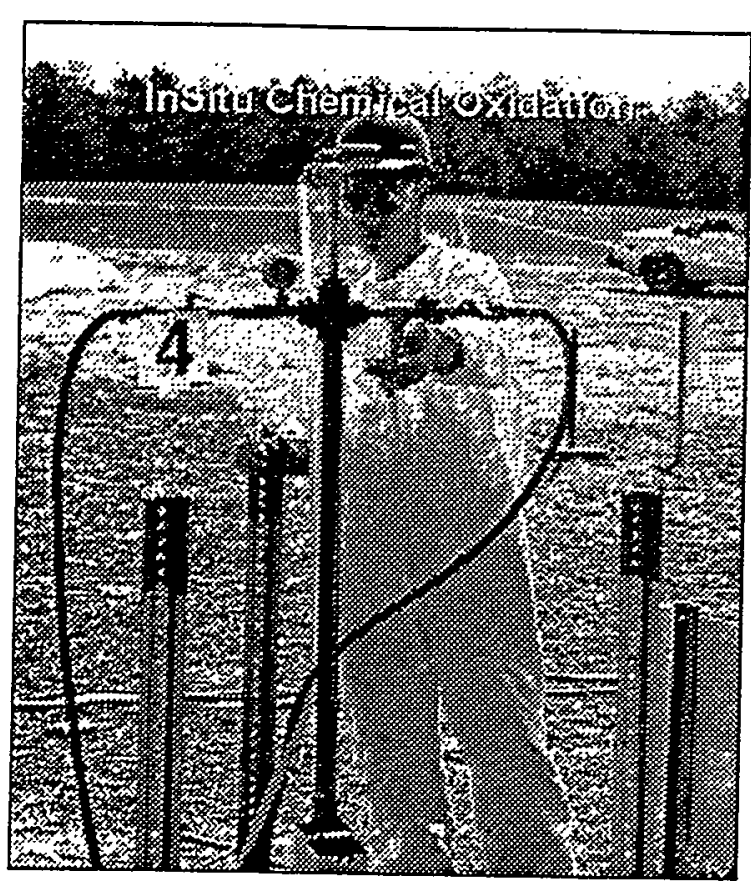

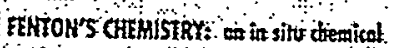
oxtogtion process ithit injetss oxtdizlatg ögents into conteminet es sol and gromintwater ond coaverts valtatite organte compobads wass:

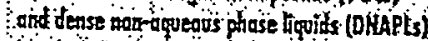

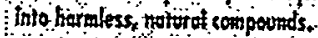

\% $1 \% 1 \% \times 1 \%$

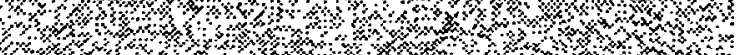

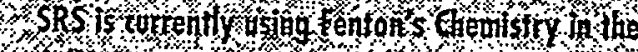

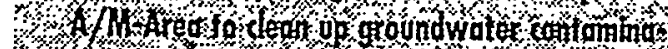

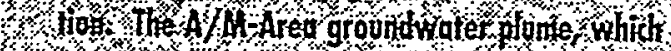

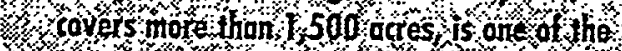
作

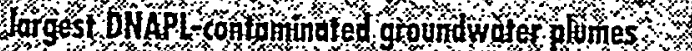

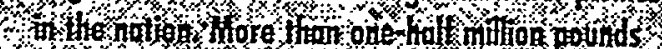

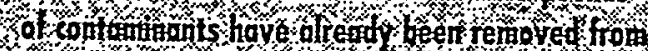

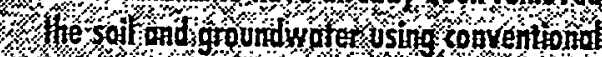

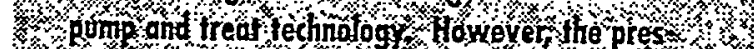

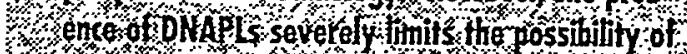

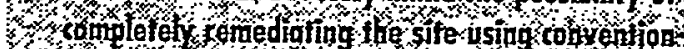
\% 8 of

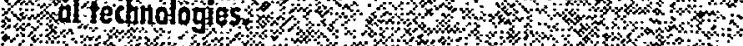

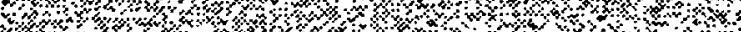

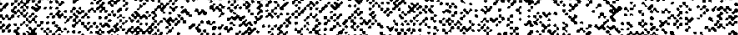

\section{In Situ Chemical Oxidation}

Grade

Injector

\section{Sand}

Silt

clay

DNAPLS

Groundwater

Contaminant Plume

Aquitard 


\section{WSRC-ms-98-00807}

$\mathrm{H}$ orizontal well technology is an innovative concept developed at SRS in 1987. Wells installed in the lateral planes of the subsurface improve access to subsurfaces and facilitate characterization, HORIZONTAL WLtLS in a situ bioremediotion system that ojtixes if instoltation of wells in the lateral plenes of the sobsoffoce to stinu-s. Iato aerobte biodegradation al contumition'ts in: underground wote ond soil: : monitoring, and remediation of contaminated groundwater and soil.

During remediation, horizontal wells are placed in the saturated zone, and media such as atmospheric air, nutrients, and even methane are injected into the wells to stimulate the metabolic breakdown of contaminants by native microbes living in the contaminated region. This process naturally biodegrades the constituents of concern.

SRS conducted its first full-scale horizontal well demonstration in 1988 when it showed how the wells could be used to expedite the cleanup of organic contaminants at the M-Area Basin. Since that time, the commercial sector has embraced horizontal well technology as a viable remediation technology alternative. In addition

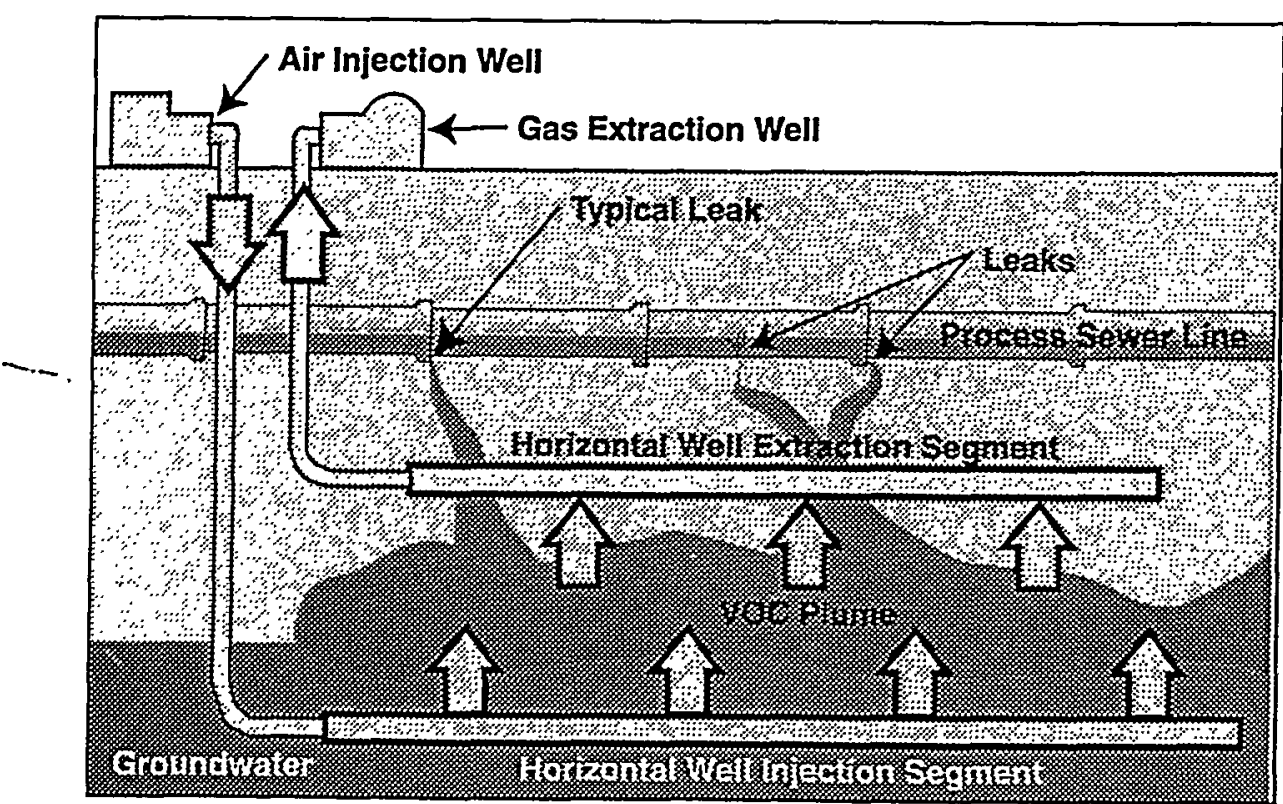

to teaching a variety of seminars on the topic of horizontal wells, SRS researchers consult on the tremendous potential horizontal wells offer to environmental remediation. Deployment of horizontal wells has a number of advantages:

- maximization of the screen zone and improvement remediation efficiency

- access to contaminated areas otherwise inaccessible, such as areas beneath build. ings, ponds, and landfills

- installation along the leading edge of a contaminant plume or at a property boundary for hydraulic control

- reduction of operations and maintenance costs resulting from a larger zone of influence and fewer wells.

Although installation costs are higher for horizontal wells, over the life of the project, the improved treatment coverage results in cost savings greater than two times that of vertical wells. Additionally, the use of in situ technology greatly reduces the generation of Investigative Derived Waste (IDW). 


\title{
CUSRL-MS- $98-00807$
}
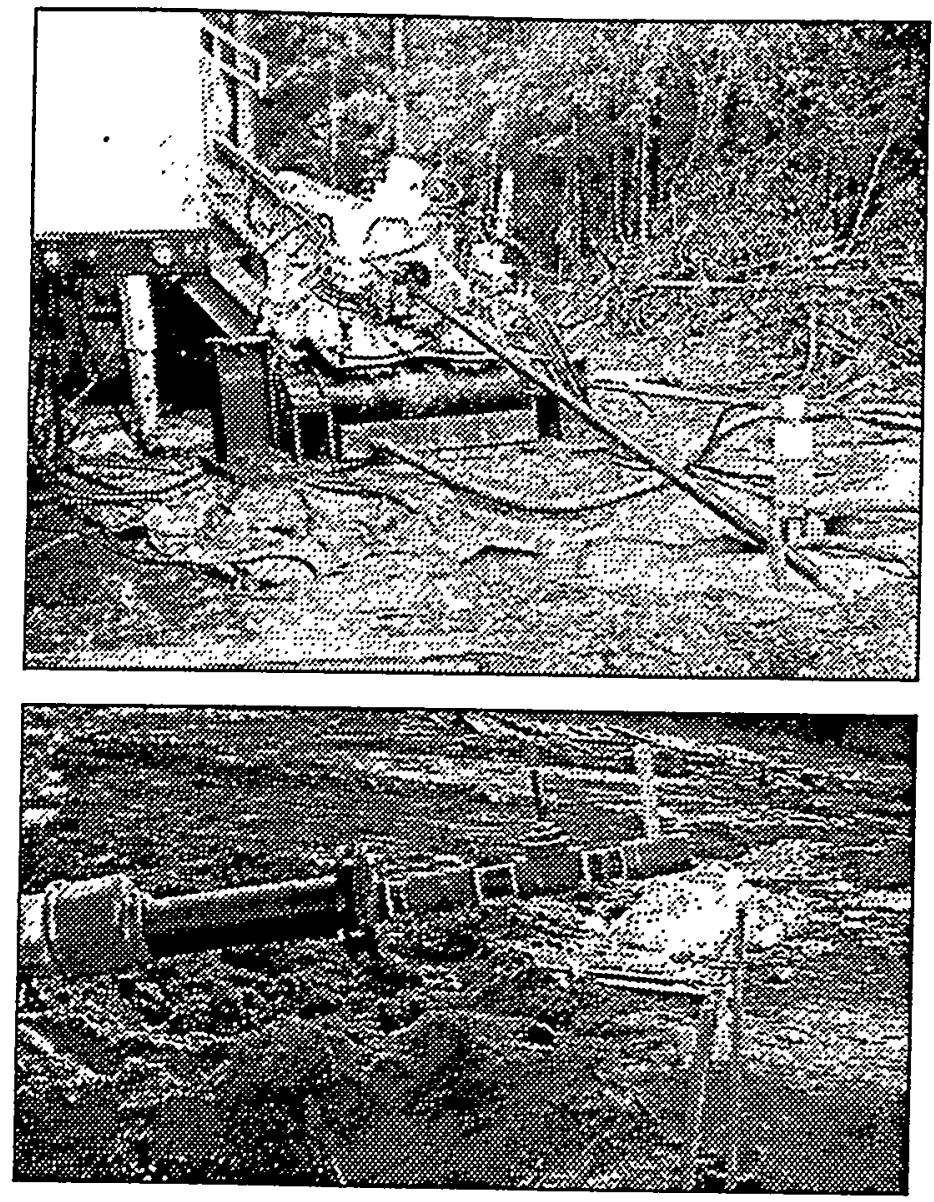

HORIZO MTA. WELLS system that bitlizes tbe intulation of welts in the loterat plases of the vibsorfuce to stimiv tate cerobie brodegradition of contomiants in vadergand walle onit soit

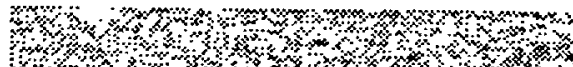

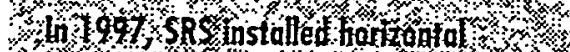

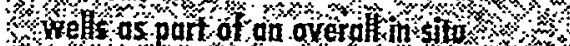

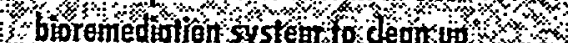

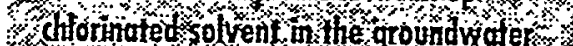

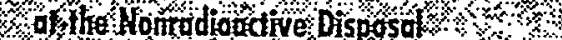

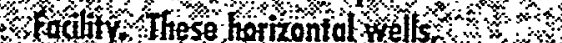
of tov of of to the secord

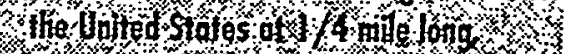

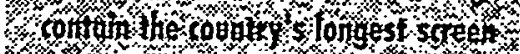

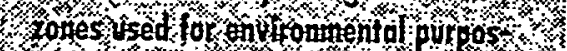

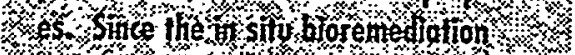

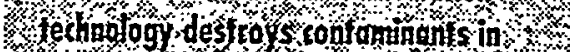

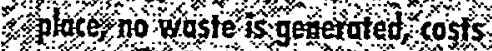

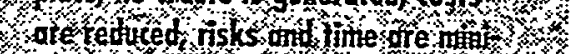

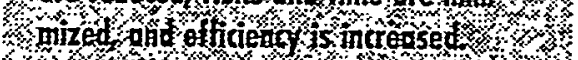
on \% 3 \%०

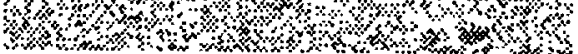

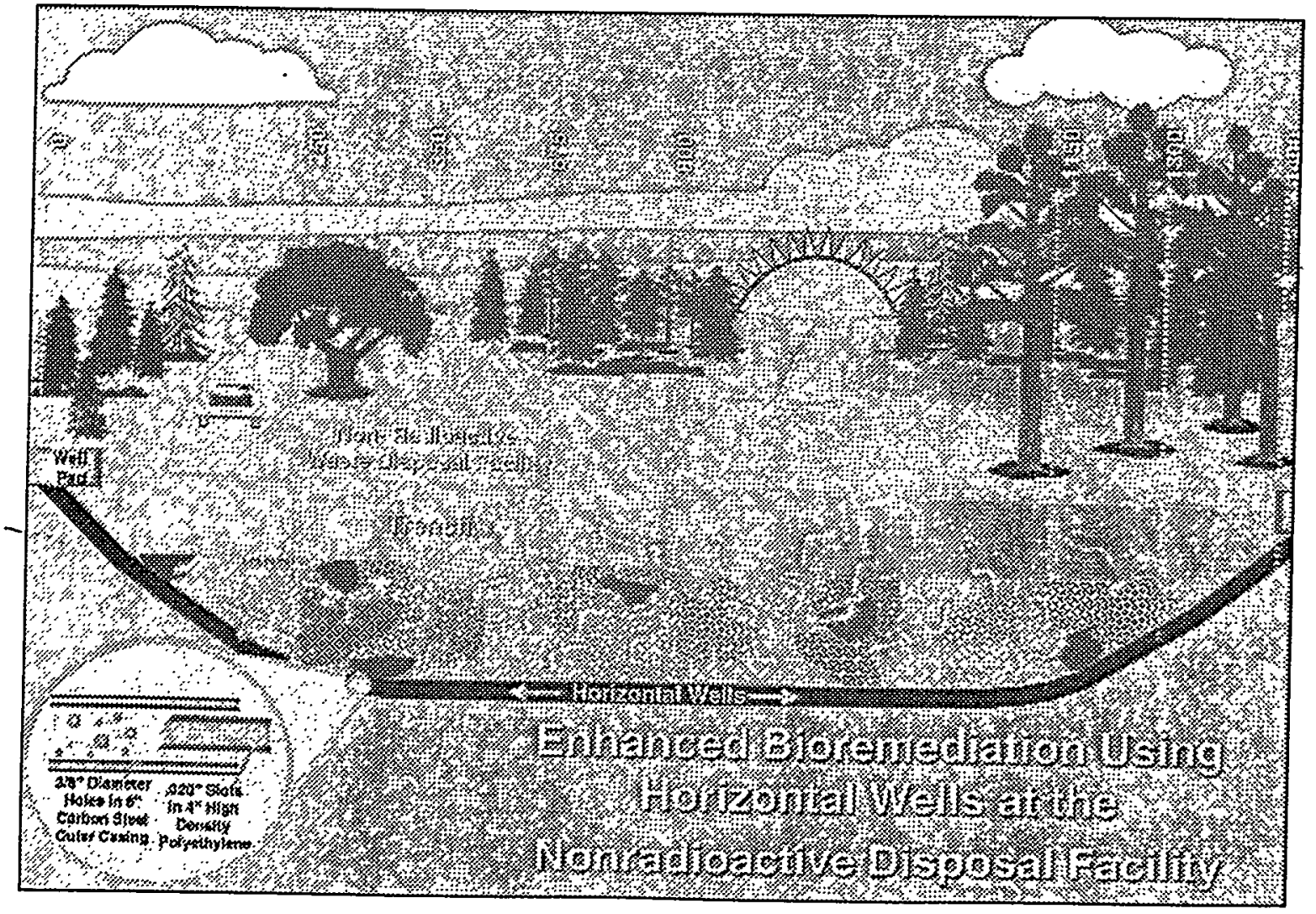




\section{WSRC-ms-98-00807}

COAL PIE RUHOFF BEAEFICAL RELSE recyling of woste frowis a supertunes silo io public usio

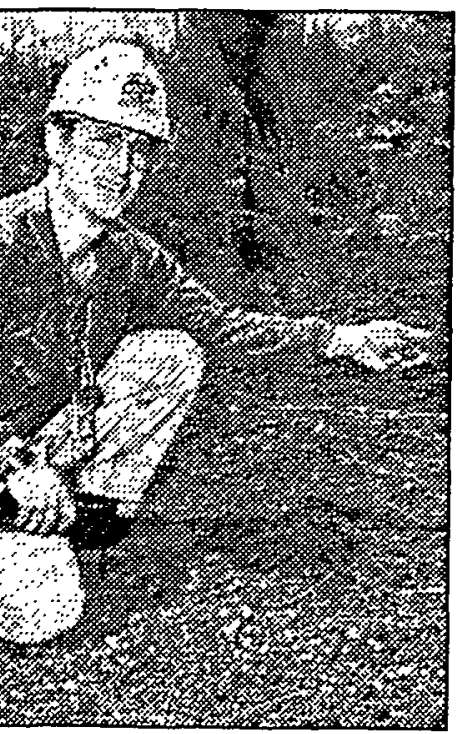

A n innovative approach to cleaning up four SRS coal piles and their runoff basins is resulting in a savings of more than $\$ 11$ million over the next five years, a reduced cleanup time of 92 months, and the beneficial reuse of waste that would otherwise require disposal in a permitted landfill.

Coal pile runoff basins were constructed at SRS in the late 1970's and early 1980 's for the purpose of protecting surface water from coal pile contaminants such as suspended solids, sulfides, metals, radionuclides, and semi-volatile organic compounds; all of these constituents occur naturally in coal.

When four of the seven SRS coal piles were no longer needed, the Site proposed a removal action to regulators. The proposal involved removing all visible coal and coal sediments from the basins, securing conveyance structures, backfilling with clean native soil to eliminate ponding and reduce infiltration, restoring the basins to natural grade, and establishing a vegetative cover to prevent erosion.

From the beginning, SRS acknowledged to EPA and the South Carolina Department of Health and Environmental Control (SCDHEC) that the project would generate many tons of waste that weren't sufficient for burning or energy recovery. In cooperation with the regulators, SRS determined that the coal sediment should be otherwise processed for beneficial reuse - the first time SRS had recycled a Superfund or CERCLA (Comprehensive Environmental Response, Compensation and Liability Act) waste for public consumption.

Starting in April 1997, more than 13,000 tons of coal and sediments were transported to an EPA- and SCDHEC-approved facility in Summerville, SC. The waste was processed so contaminants were bound and could not leach into the environment. The end product was later used as road base material under public highways.

Typically, this waste would have been shipped offsite to a permitted landfill facility. Disposal costs would have been $\$ 70$ per ton instead of the $\$ 23$ per ton cost of recycling. The $\$ 47$ per ton difference allows SRS to realize a $\$ 615,000$ beneficial reuse savings which can be allocated to the remediation of other waste sites.

Cost savings associated with accelerated cleanup (a reduction in cleanup time of 92 months) will permit the potential redirection of more than $\$ 11$ million in budget to other remedial activities. Other benefits of the approach include:

- improved groundwater conditions resulting from accelerated cleanup of the contamination source

- elimination of direct exposure and excavated soil pathways resulting from backfilling of remaining basin subsoils

- elimination of ponding and a reduction in infiltration of $44-66 \%$ because of regrading

- elimination of more than 25 documents scheduled for submittal to the regulators. 

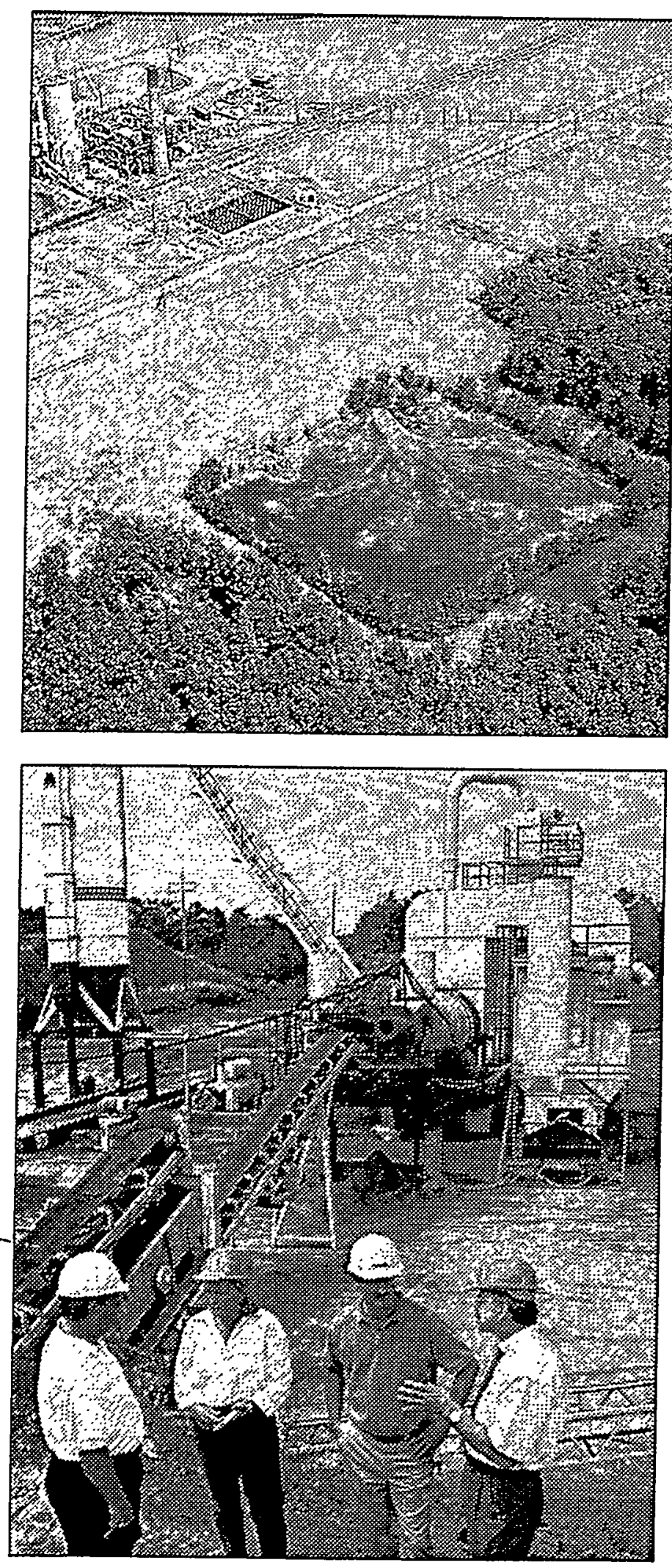

COAS PLE RLAOTK BENETCAL RiLSE:

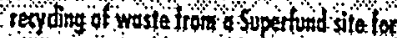
putile ese

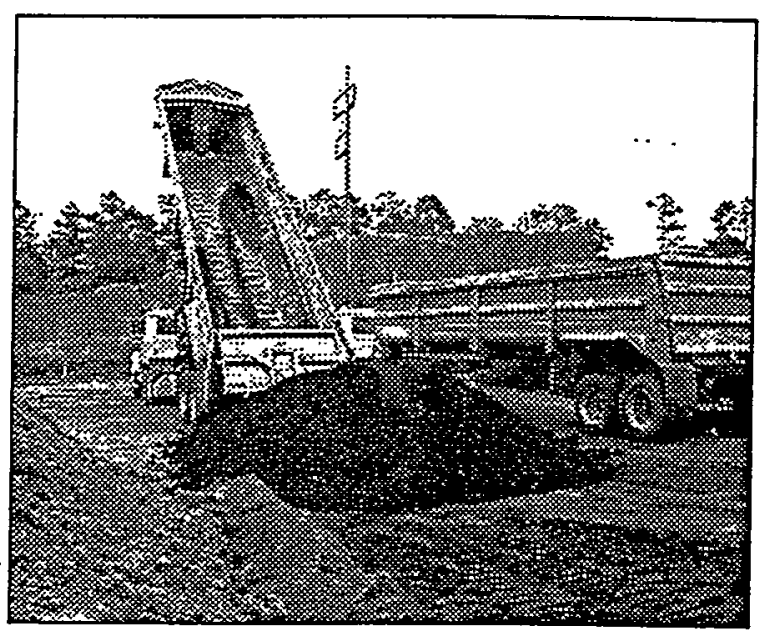

\%

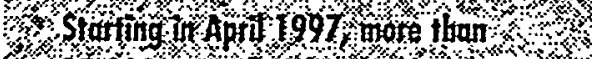

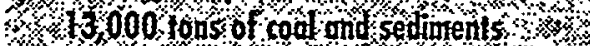

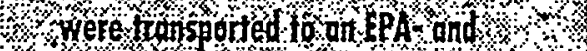

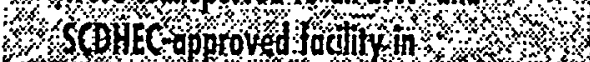

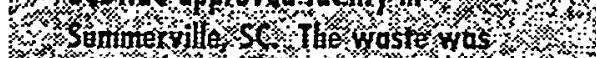

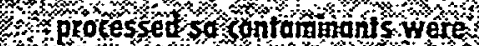

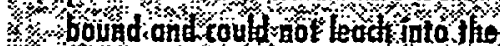

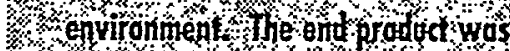
s...

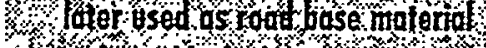

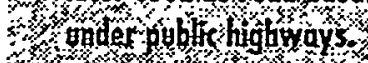

48 .

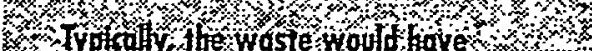

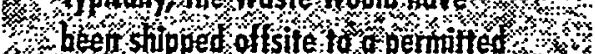

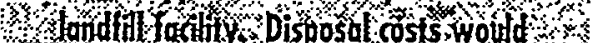

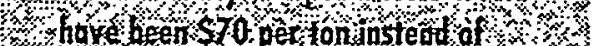

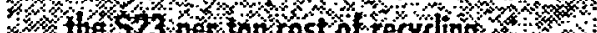

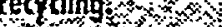

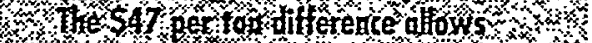

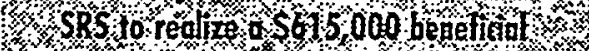

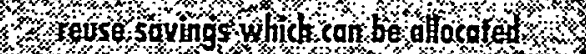

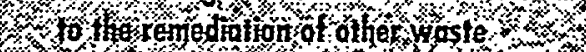

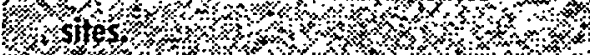

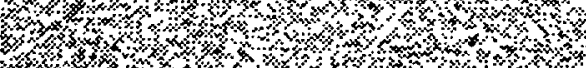
, 
CONTROLLE IOW STREIGTH MATERIAL

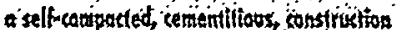

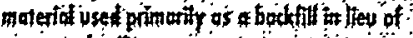
coopoxted sot:

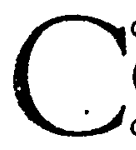

ontrolled Low Strength Material (CLSM) is a self-compacted cementitious construction material used primarily as a backfill in lieu of compacted soils. As a result of innovative thinking, SRS engineers developed a CLSM design process that results in the beneficial reuse of a by-product waste material.

Ashes collected from storage and disposal basins are used as raw material in the preparation of the CLSM design mix. Incorporating the ash material into the mix not only saves the site the cost of CLSM raw materials but uses a by-product waste material that would have required disposal.
SRS plans to use CLSM in radioactively contaminated areas because it can be pumped into place remotely, eliminating the requirement for construction personnel to handle it in the contaminated area. Use of CLSM reduces exposure risks and requires less time and labor. It can also be placed in wet weather, whereas soil cannot be compacted in the rain.

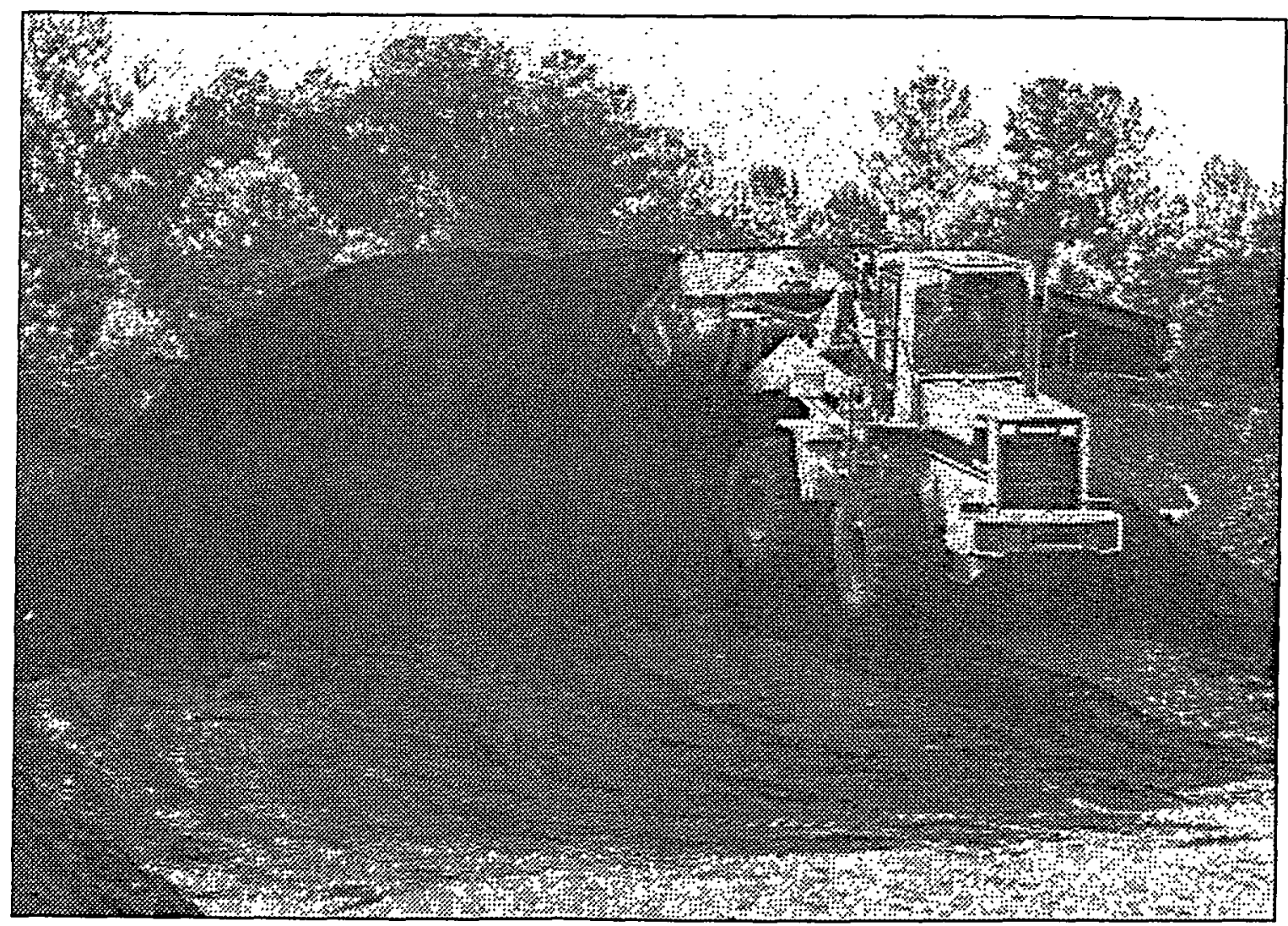




\section{$\omega S R C-m s-98-00807$}

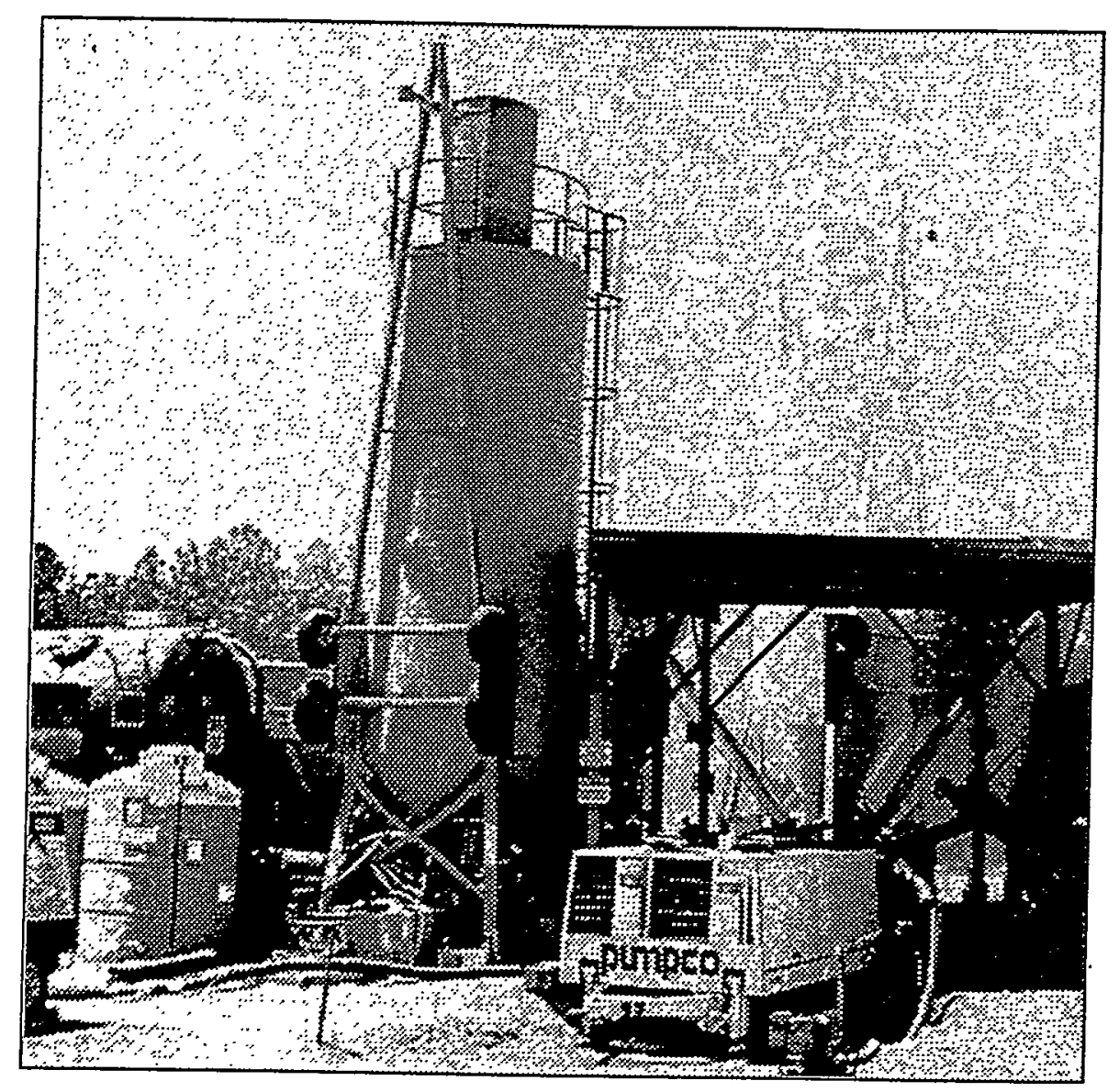

CONTROLED IOW STRENGTH MATERIAL:a self-composited cenentiliow, constration

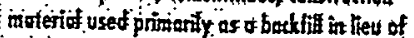
rompated soit:
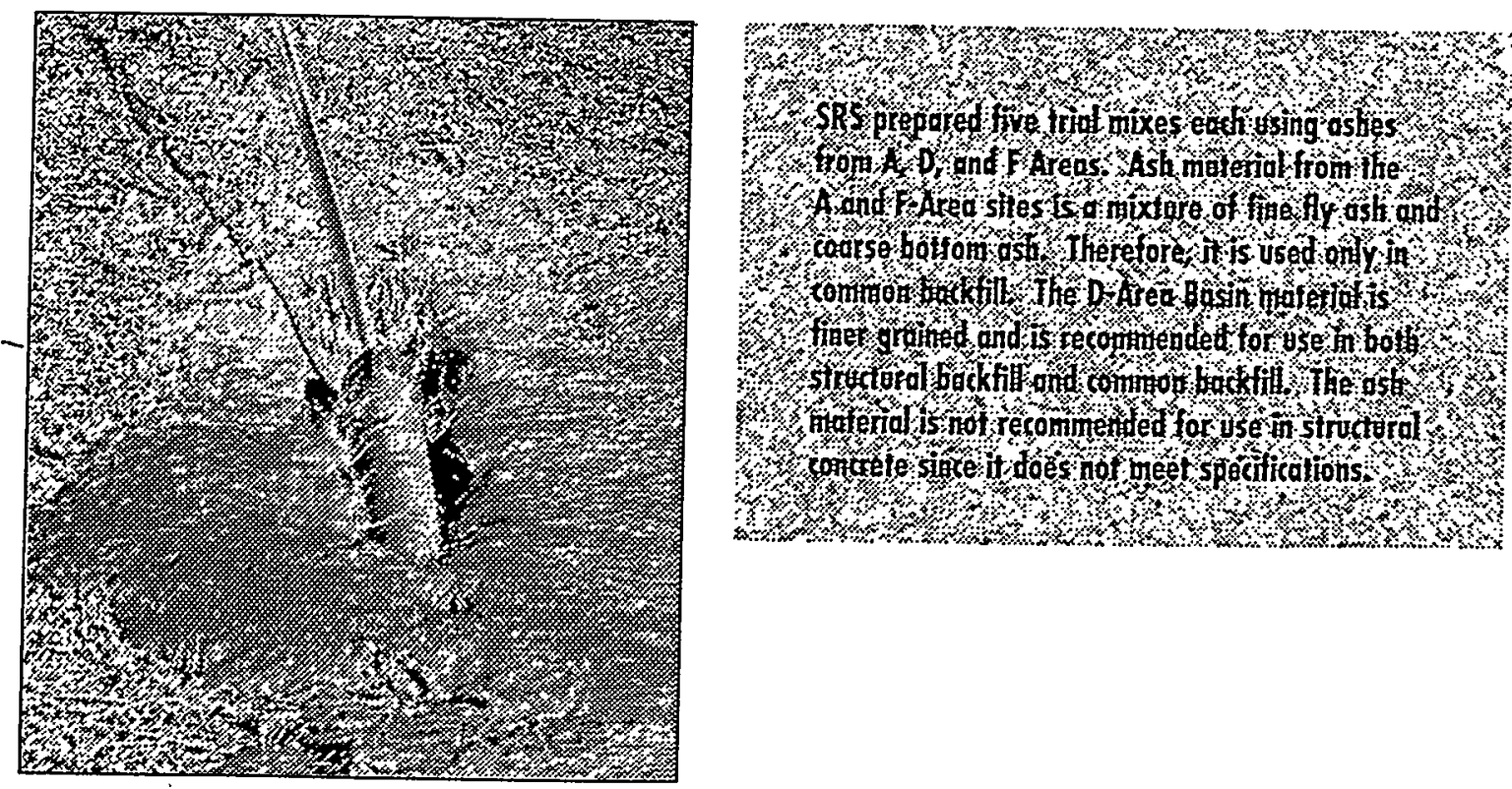


\section{WSRC-ms. $98 \cdot 00807$}

$\mathrm{D}$ ynamic Underground Stripping (DUS) is an innovative in situ treatment system that cleans up soil and groundwater contaminated with organic compounds by combining several remediation technologies.

The synergy of the components of the

DYNAML UHDERGROLHD STRIPPING on H.

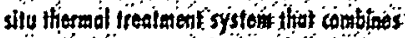

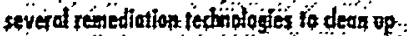

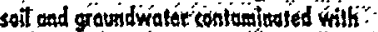
organic compoutids.
DUS system results in a remediation tool that effectively cleans up contamination above and below the water table and is especially well suited for sites with interbedded sand and clay layers.

The primary technologies utilized by the DUS system are:

- Steam Injection and Vacuum Extraction - Injection wells that supply steam and electric current are drilled around an area of concentrated contamination. As permeable soils are heated to the boiling point, a steam front develops in the subsurface and volatile organic contaminants are vaporized from the hot soil. The steam moves from the

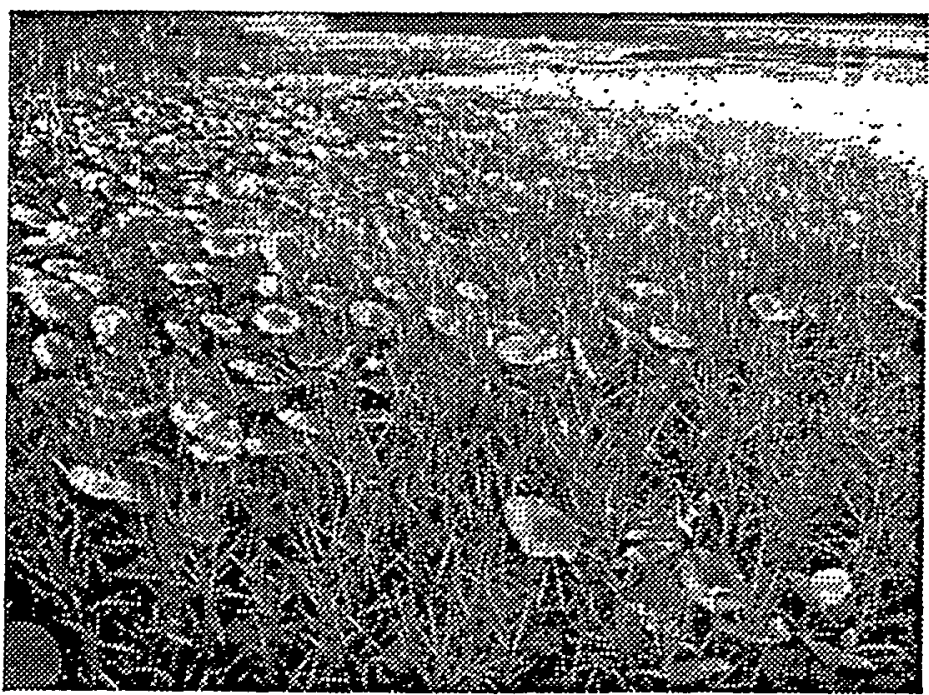

injection wells to the vacuum extraction wells located in the center of the contaminated area. The extraction wells remove the contaminants.

- Electrical Resistance Heating - Electric current is used to heat impermeable soils. Water and contaminants trapped in these relatively conductive regions are vaporized and forced into the steam zone for vacuum extraction.

- Underground Imaging and Monitoring - Several geophysical techniques are used to delineate the heated area and track the underground movement of steam to ensure total cleanup and precise process control.

In situ destruction of contaminants results from the thermally accelerated oxidation processes converting harmful chemicals into carbon dioxide and water. Raising the temperature of the soil and groundwater leads to rapid removal of organic contaminants primarily because of the dominating mechanism of increased volatility and steam stripping when the mixture of water and DNAPL reaches the boiling point.

This in situ treatment system offers some of the same pollution prevention benefits that in situ chemical oxidation (Fenton's Chemistry) and in situ bioremediation (horizontal wells) offer. Waste volumes are minimized because the waste is vaporized and therefore concentrated in the treatment process. Additionally, DUS may make it possible for solvents to be recycled. 


\section{WSRC- $m s-98 \cdot 00807$}

OYNAHIC UNDERGROUND STRIPPTHEY OO

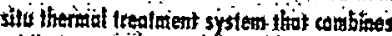

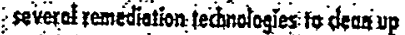

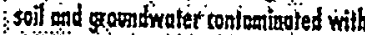
orgonter wingovids

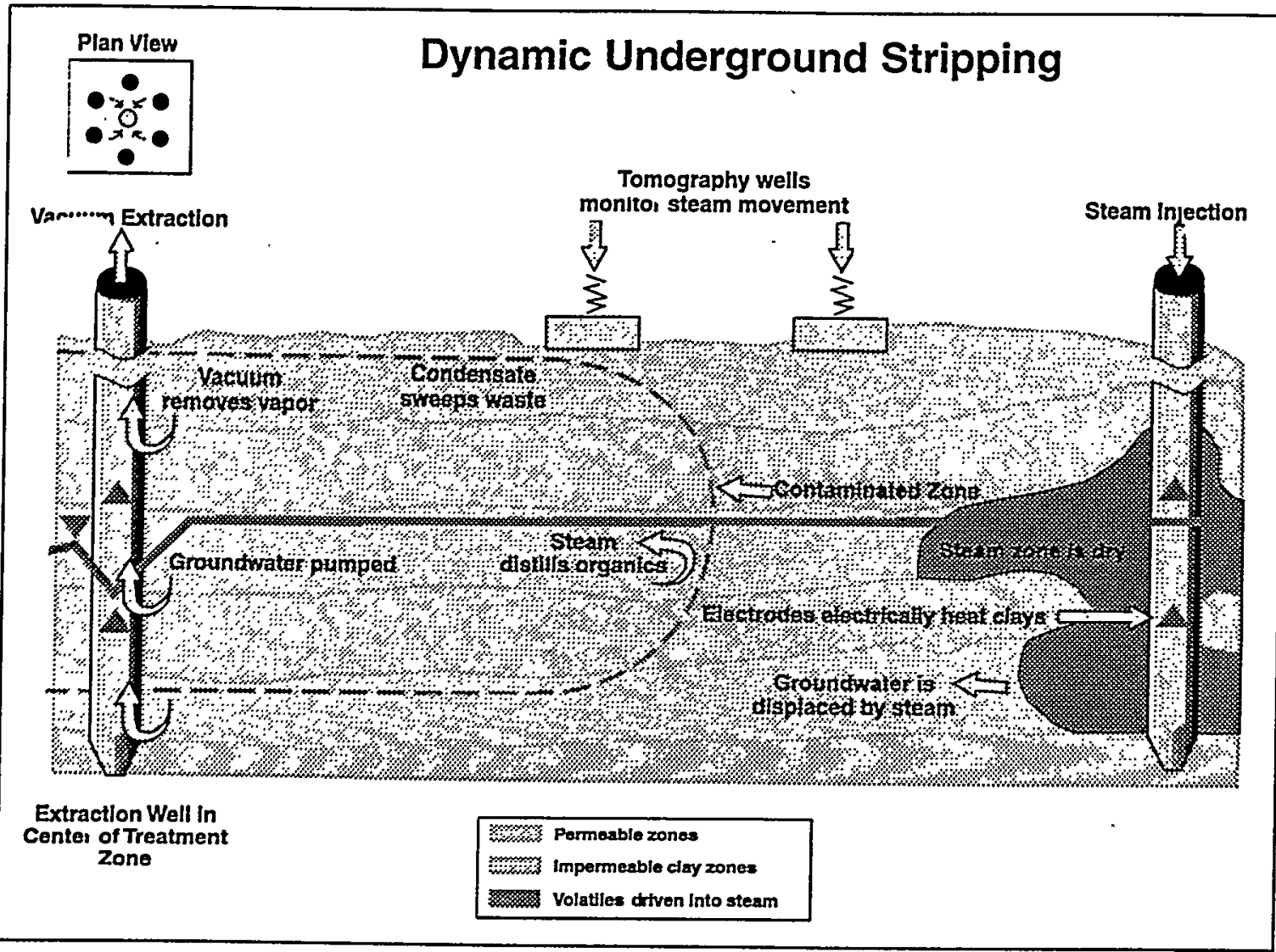

DUS also provides an accelerated method for site cleanup with a low overall cost. Thermally enhanced cleanup currently costs between $\$ 11$ and $\$ 37$ per cubic yard of contaminated soil (including energy costs). Additionally, the technology reduces cleanup time from decades to months. DUS can remediate a site in six to nine

- months while a conventional pump and treat system can take up to thirty years.

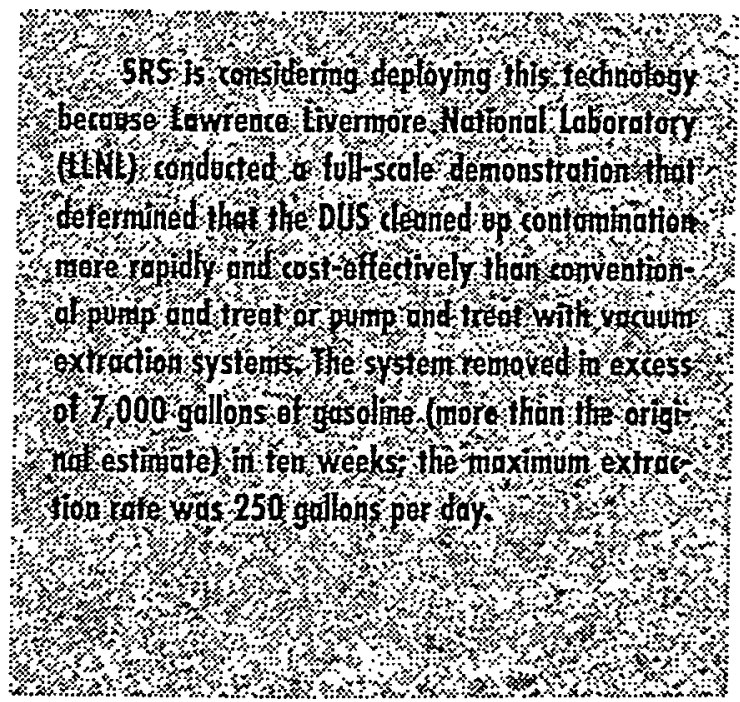




\section{COSRC-ms-98-00807}

$\mathrm{P}$ hytoremediation is a technology that capitalizes on the ability of naturally occurring bacteria and fungi in root systems to clean up many types of organic contaminants, including chlorinated solvents, chlorinated pesticides, organophosphate insecti-

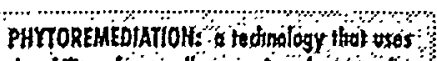

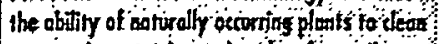

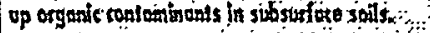

cides, petroleum hydrocarbons, creosote, and refinery wastes. It is most effective when the contaminants are in the top two to three feet of the soil profile, within the reach of plant roots.

Phytoremediation is best suited for surface soils contaminated with intermediate levels of organic wastes since contaminant concentrations above certain levels can be toxic to plants. Technicians conduct preliminary soil testing to determine the type and level of contamination, and then plants are selected based on their resistance to the specific contaminant(s).

The technology has some limitations such as the amount of time required (sometimes several growing seasons) and the stage of technology

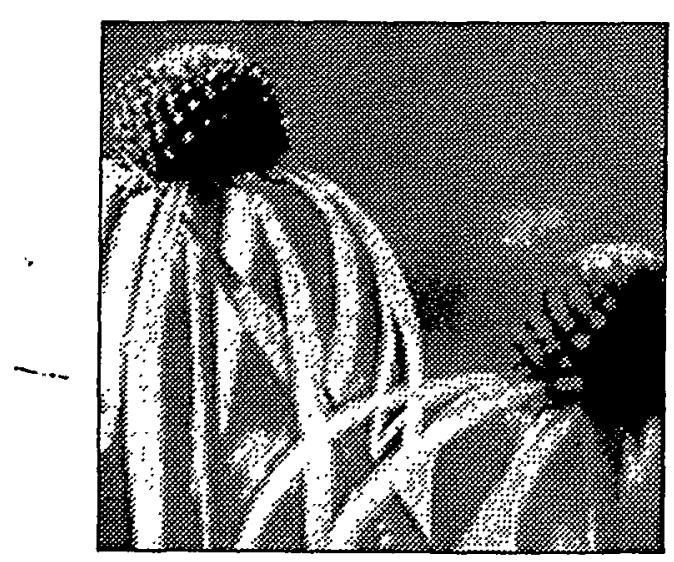

development for some applications. In spite of these limitations, phytoremediation is particularly well suited for sites where large areas of surface soil are contaminated with intermediate levels of organic chemical pollutants. Since conventional agriculture equipment and supplies are used, the technology cost is extremely low, compared to other soil remediation technologies such as soil removal and soil washing.

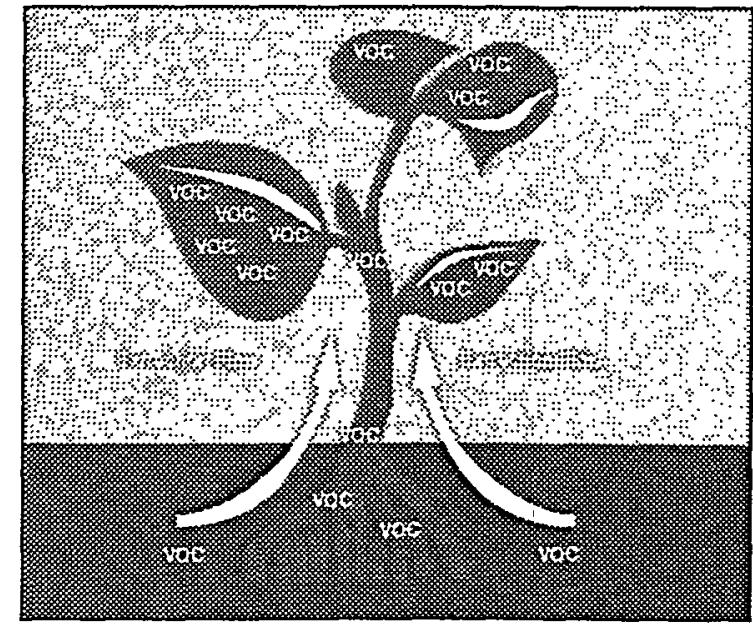

The pollution prevention benefit of this in situ technology is that it minimizes waste by eliminating the removal and transportation of contaminated material from one site to another. In many cases the organic chemical contaminants are completely destroyed (converted to carbon dioxide) rather than immobilized or stored. Another benefit of this "green technology" is that it reclaims polluted sites so that they can be used for agricultural purposes. The vegetation also prevents the spread of contaminants to other sites by reducing soil erosion by wind and water.

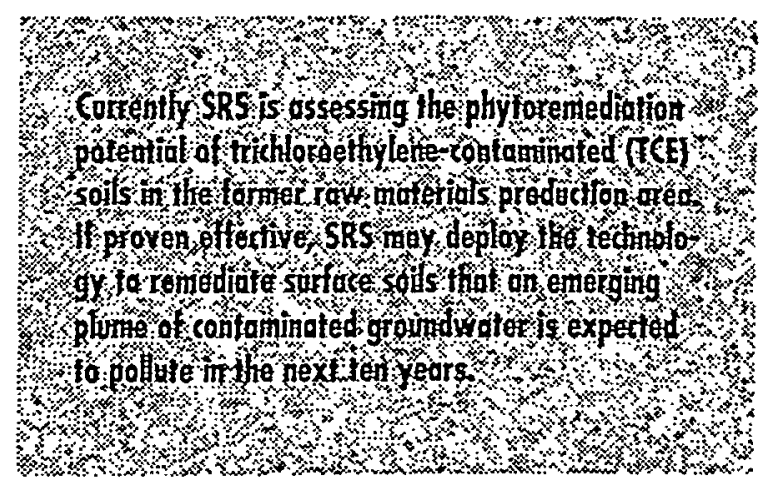




\section{WSRL-MS-98-00807}

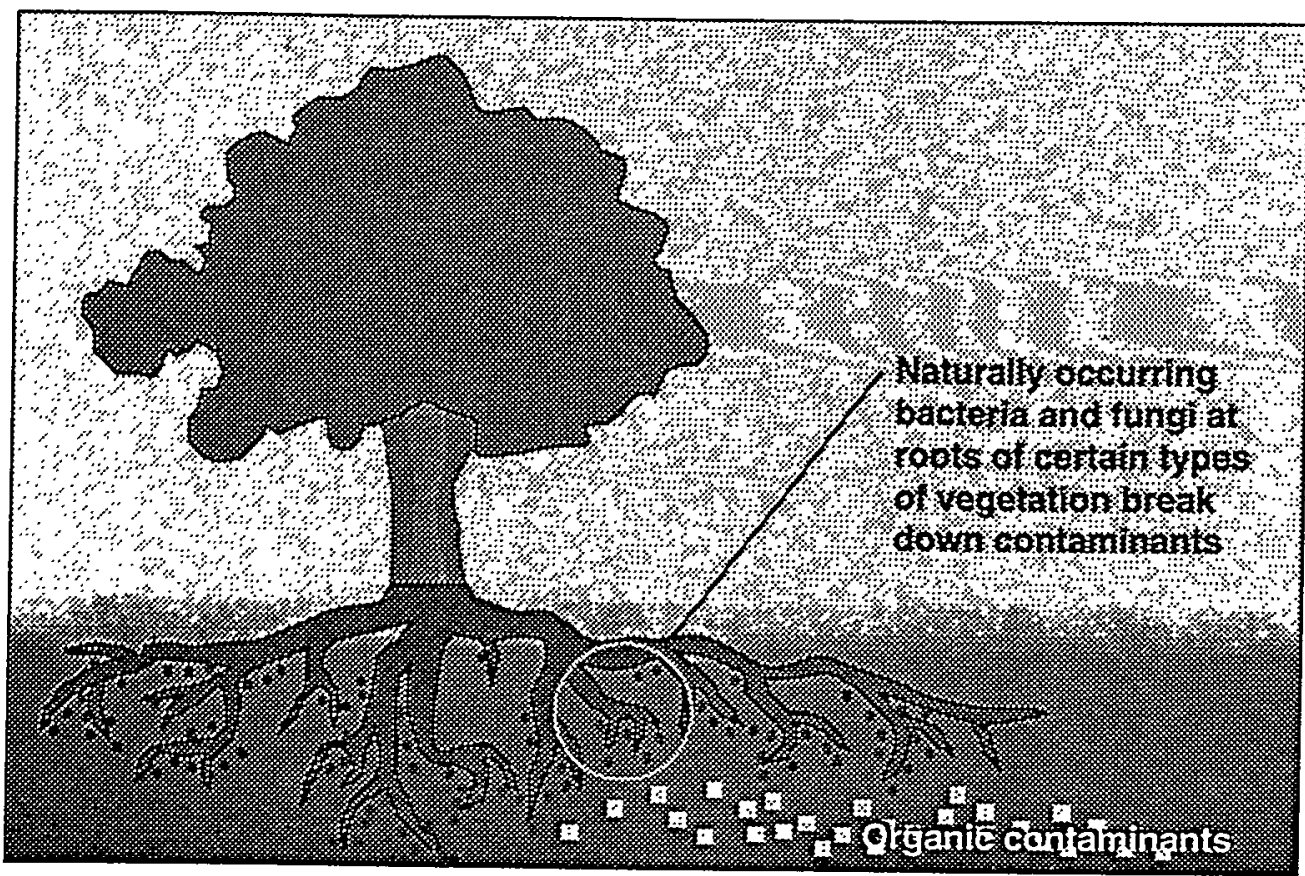

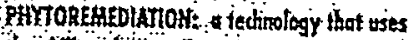

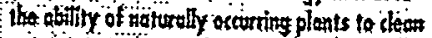

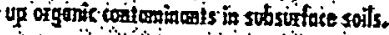

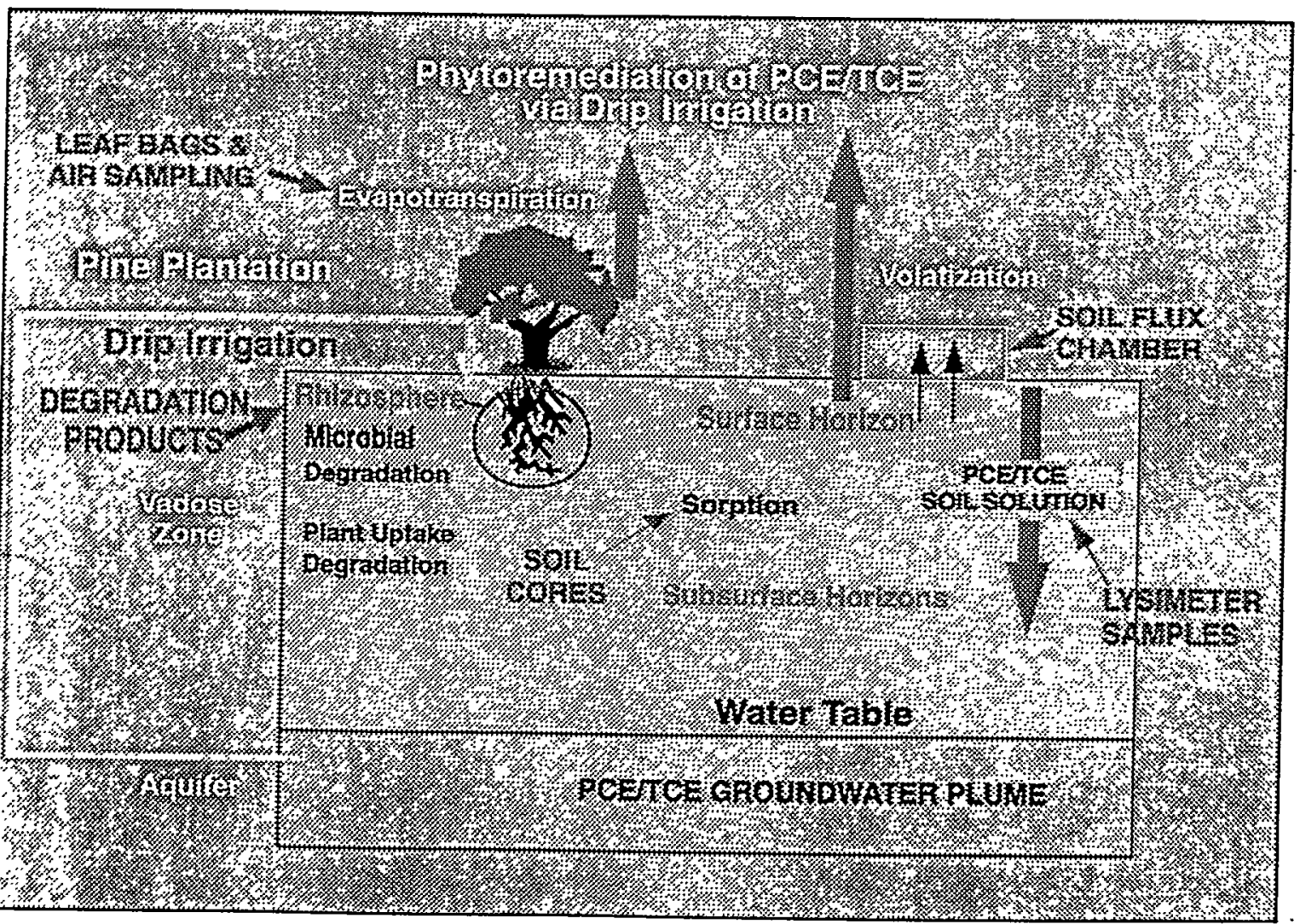




\section{WSRC-ms-98-00807}

T he PHOSter system is a breakthrough process developed by SRS that harnesses the natural detoxification capabilities of bioremediation systems. PHOSter, recipient of a 1995 National Federal Laboratory Consortium Award for Excellence in Technology PHQSTER o tedindogy that effedively delevers phasphores nutitents lo stiniolote

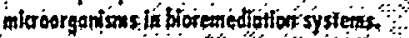
ancong

Transfer and a 1996 R\&D 100 Winner, provides controlled addition of phosphorous, a critical nutrient, into sites contaminated with organic compounds. The PHOSter process stimulates the growth of natural microorganisms by controlling their nutrition; these organisms grow and efficiently consume all types of organic contaminants, such as gasoline, oil, and industrial solvents.

The PHOSter system injects a mixture of air and triethyl phosphate through horizontal wells to encourage the growth of microorganisms that destroy contaminants in situ. The process works

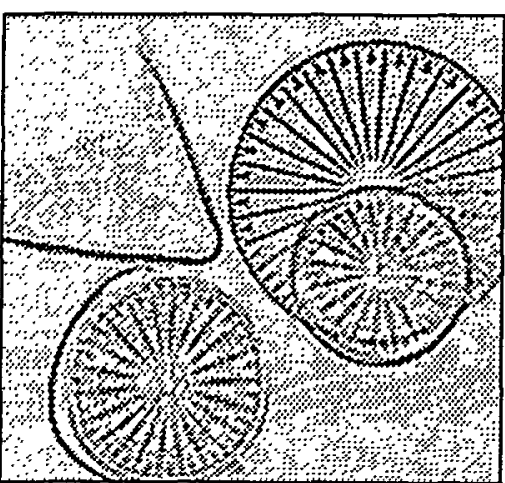

with any system that delivers nutrients (in a gas phase) to a microbial population in a site contaminated with chlorinated solvents. Injecting phosphorous in this gaseous form makes it highly available to the target microorganisms.

Deploying PHOSter offers a couple of pollution prevention benefits to ERD. The method enhances natural in situ remediation systems and ensures that one form of contamination is not replacing another. The phosphorous nutrient is safe and is completely consumed in the remediation process. Toxic organic chemicals are decontaminated in situ, eliminating the need to process large quantities of soil or groundwater and the need to transport contaminants to another site for later processing. Additionally, PHOSter uses minimum energy. Earlier attempts with traditional phosphorusdelivering methods failed to deliver the nutrient to a sufficient depth with a cost-effective, nonenergy-intensive method.

PHOSter eliminates or greatly reduces problems associated with previous attempts to deliver phosphorous to the biomass. It works with any system (e.g., bioventing, biosparging, etc.) that delivers nutrients in a gas phase to a microbial population in a site contaminated with chlorinated solvents. Cleanup can be performed up to 10 times faster than was previously possible. And the accelerated cleanup results in significant cost savings. 


\section{WSRC-MS- $98-00807$}
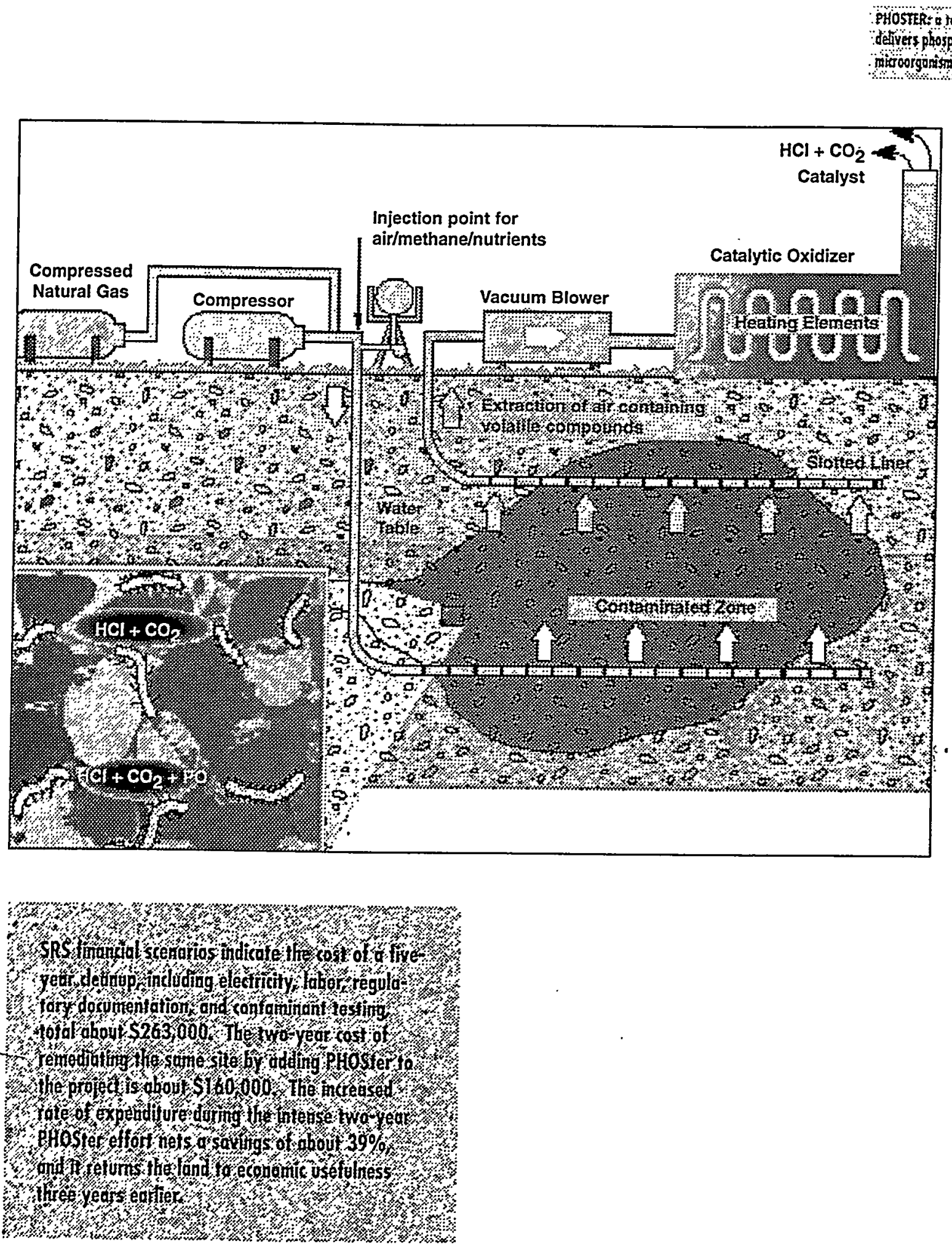


\section{WSRC-ms-98-00807}

FIED DEPLOYABLE TRITULH AKALYSIS: a renofely operated system thot messores.

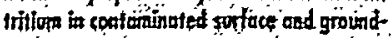
woter in sear real timo.
$\mathrm{T}$ The Field Deployable Tritium Analysis System (FDTAS) is a readily portable tritium analyzer that was developed and tested at SRS. The system is remotely operated and measures tritium in contaminated surface and groundwater in near real time.

The FDTAS consists of an automated sampling and purification system coupled with a stop/flow radiation detector that utilizes liquid scintillation counting technology. A ample from a well or surface water source is obtained. The sample then goes through a singleuse filtration and ion exchange column for in-line purification and is sent to a special cell where the purified sample is mixed with a liquid scintillation cocktail (LSC). The ISC/sample mixture is pumped into a special quartz analysis cell where it is counted and analyzed. The FDTAS can measure a background count rate of less than three counts per minute and uses a $1: 1$ LSC to sample mixture to achieve a tritium detection efficiency greater than $25 \%$.

A remote computer, connected to the system through a modem, controls the FDTAS. The status of the system is monitored from the remote station during all phases of operation. The FDTAS provides for in situ, near-real time, unattended analyses of tritium in ground and surface water.

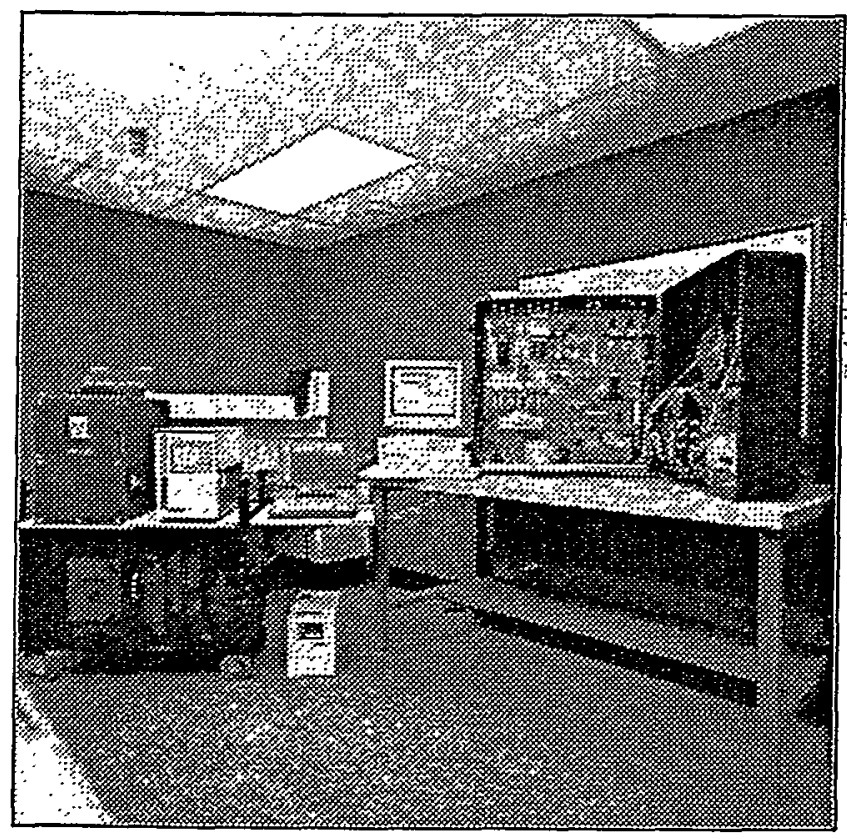




\section{$W S R C \cdot m S-98-00807$}

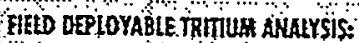

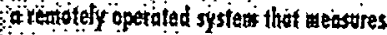

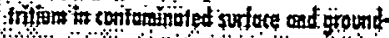
woter un net reafinter
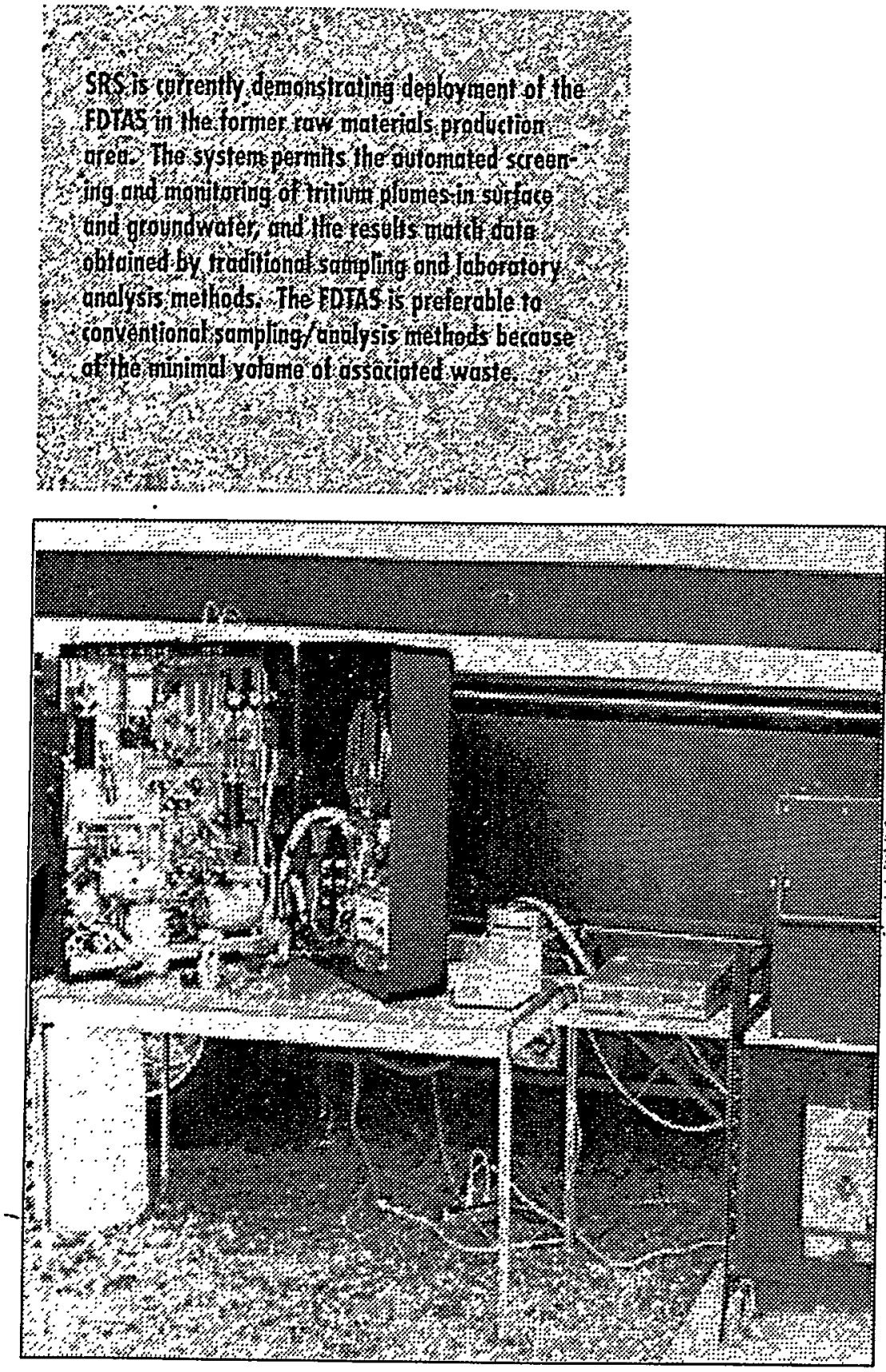


\section{Innovative thinking, innovative technology, innovative problem solving} methods... they all impact the bottom line.

IMPACF; the effect of one ithing vpont wother

1 he ERD commitment to identifying innovative $\mathrm{P} 2$ techniques and technologies has already had a significant impact on the bottom line of the SRS environmental cleanup program. Taking pollution prevention to the next level has reduced investigation-derived waste, waste generated during remediation, and waste requiring removal, treatment and disposal. Decreased waste volumes translate into reduced treatment and disposal costs and result in numerous cleanup projects being completed under budget. Recent innovations have already resulted in over $\$ 1.3$ million in savings. These reduced project costs have not only impacted the bottom line of the overall ERD budget but have expedited the site's cleanup schedule since budget surpluses are redirected to other cleanup projects awaiting funding. Technology based innovations are expected to save $\$ 300$ million dollars over the next 20 years.

The ERD commitment to innovative P2 technologies has also had an impact on cleanup budgets and schedules at other DOE, Department of Defense, industry, and university locations. The site freely exchanges information, technologies, and valuable lessons learned through sharing forums such as technical working groups, expert panels, site-to-site exchanges, international contacts, conferences, workshops, and other presentations and demonstrations. Last year the site participated in more than seventy environmental remediation technology forums. As a result, SRS technologies, such as horizontal wells, PHOSter, and the Field Deployable Tritium Analysis System were shared with other DOE, DOD, and local government facilities. Likewise SRS leveraged its cleanup resources as the beneficiary of approximately ten shared innovative concepts.

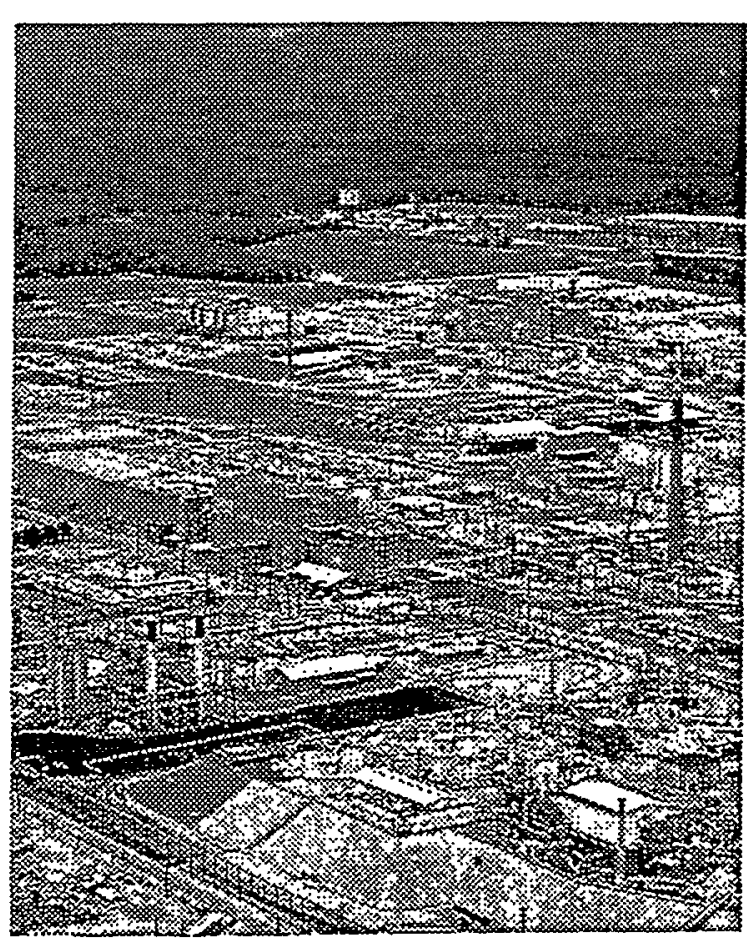

